\title{
Thesis Examination Timetabling using Genetic Algorithm
}

\author{
Susana Limanto \\ Department of Informatics Engineering \\ Faculty of Engineering \\ Universitas Surabaya (UBAYA) \\ Surabaya, Indonesia \\ susana@staff.ubaya.ac.id
}

\author{
Njoto Benarkah \\ Department of Informatics Engineering \\ Faculty of Engineering \\ Universitas Surabaya (UBAYA) \\ Surabaya, Indonesia \\ benarkah@staff.ubaya.ac.id
}

\author{
Tyrza Adelia \\ Department of Informatics Engineering \\ Faculty of Engineering \\ Universitas Surabaya (UBAYA) \\ Surabaya, Indonesia \\ tyrza@staff.ubaya.ac.id
}

\begin{abstract}
Thesis examination is one of the requirements to complete a graduation course. At the Department of Informatics Engineering Universitas Surabaya, thesis examination begins with organizing the exam timetable to determine the time, examiner, and room by using traditional scheduling system. The disadvantage of the system is that the process takes a relatively long time, which is influenced by factors such as the lecturer's work schedule and the availability of the room. Program coordinator responsible for the organization of the thesis timetable must perform a thorough analysis so that the schedule does not clash with the teaching schedule and the availability of the room. In addition, the number of lecturers as examiner between one and the other has to be distributed equally. To facilitate the program coordinator, a web-based system using genetic algorithm was developed for the efficiency of thesis examination timetabling. Testing and evaluation process are conducted by taking a random respondent in accordance with the user category. The results show that the system developed can improve the efficiency of time, effort, and cost.
\end{abstract}

Keywords- Genetic Algorithm, Thesis Examination Timetabling.

\section{INTRODUCTION}

Thesis is a scientific paper that is made in accordance with the scientific field with the direction of the supervisor as one of the requirements to complete studies in higher education [1]. The results of the thesis will be assessed in front of 4 examiners [2]. Students can take a thesis exam at least 3 months after the submission. Prior to 2011, the department of Informatics Engineering University of Surabaya (Ubaya) opened a thesis exam 5 times each year. This is one of the reasons for the long duration of the student's thesis work because they cannot take the thesis exam even though it is finished. To overcome this, the Informatics Engineering department opens thesis examination schedule on average 10 times each year.

The thesis exam begins with the preparation of the exam schedule which starts with the administrator announcing the thesis exam schedule via a notice board and e-mail to all students who are taking a thesis. Then, the administrator distributes the exam readiness form to the lecturers. Three days later, the administrator will collect the exam readiness form from all lecturers. After that, the administrator will open the exam schedule \& room based on the exam readiness form and the availability of room. Lastly, the program coordinator will create examination timetable by determine the examiner according to the exam readiness form between 4 lecturers, the suitability of the scientific field of each lecturer, and the equal distribution of the number of students examined. Scheduling is the process of allocating resources that aims for a set of tasks to be selected within a certain time frame [3].

A lot of research has been done related to thesis examination timetabling. To overcome the problems related to the preparation of the seminars and thesis examination timetabling in Unikom, Wibawa and Fachrizal in his research has developed an application. The timetabling criteria used are room availability, and time availability from supervisors and candidate examiners [4]. The results of the study indicate that the applications developed can avoid clash of lecturer schedules [4]. The same problem is experienced by Politeknik Negri Malang and STMIK STIKOM Indonesia. A study was developed by Cahyo, Rozi, and Ariyanto to overcome the problems at the Politeknik Negri Malang. The limitation imposed are that the supervisor is not allowed to test the guided student, one of the supervisors must be present when the student who is being guided takes the thesis examination, the examiner lecturer may not test in another room at the same session, and the availability of the room [5]. The results showed that timetabling had met the existing criteria. Whereas to overcome the problems that exist in STMIK STIKOM Indonesia, Budayasa and Dirgayusari develop a scheduling application so that there are no clashes of room and examiners [6].

All research on the existing thesis exam timetabling only uses the criteria of room availability, time availability from the supervisor lecturer and candidate examiners, and avoids any clash of schedules both from the lecturer and the room. There are other criteria that should be taken into account in the thesis exam timetabling as required by the Indonesian government which is not taken into account in the existing research, specifically the minimum requirements for functional positions and the number of examiners [7]. In addition, the existing research also does not take into account the equal distribution of the number of students examined by each lecturer. Therefore, a study was developed on the thesis exam timetabling that added these three criteria.

\section{Methodology}

The process of collecting data is done in several steps including observation, interviews to some respondents and taking data from the traditional system of thesis timetabling. 
Observation is conducted to get ideas and information related to timetabling system at the department of Informatics Engineering. In addition, interviews with respondents related with the system are also conducted to collect information about problems that arise during timetabling. Respondents for interviews include heads of departments, program coordinators, and administrators who have been managing the thesis examination.

The system is developed using genetic algorithm. The genetic algorithm is an optimization technique based on the principle of natural selection and genetics. This algorithm is a simple and relatively easy to implement [6]. According to Huynh et al., Genetic algorithms have good convergence behavior to solve scheduling problems [8].

\section{SYSTEM IMPLEMENTATION}

The thesis examination timetabling system is designed to not only meet the needs of the Informatics Engineering department Ubaya, but also to be easy to develop.

\section{A. Data Design}

The first design to do is data design. The data for the thesis examination timetabling is designed to integrate with the Academic Information System (SIA) central database owned by UBAYA. This is intended to avoid the occurrence of data redundancy and inconsistency. However, since the scheduling procedure of thesis examination of each study program in Universitas Surabaya varies, not all the required data is available in the central database. The University's SIA database is only used to manage data related to the academic activities of all existing courses at UBAYA which have been standardized equally for all courses.

The data required for the timetabling system taken from the University's SIA database are mahasiswa table, mhsambilmk table, skripsikp table, skripsikppembimbing table, notaupp table, notauppdetail table, karyawan table, employment education history (pe_rwtpendidikan) table, employment structural history (pe_rwtstruktural) table, and room table. The mhsambilmk table is used to store the list of courses taken by students each semester including thesis. The skripsikp and skripsikppembimbing tables are used to store thesis and apprentice data from students including their supervisors. While notaupp, and notauppdetail used to store tuition fees (UPP) payment data which has been done by the students. The pe_rwtpendidikan table is used to store lecturer's education history data. This table is used to find out whether a lecturer eligible of examining thesis or whether it is in accordance with the rules of the Higher Education Service. The pe_rwtstruktural table is used to determine the lecturer's position related to the rights determination of the system access. The data design for the thesis examination timetable system is described in the form of Entity Relationship Diagram (ERD) which can be seen in Figure 1. Entities representing tables from the University's SIA database are not depicted as a whole in Figure 1, only entities that are directly connected with the additional entity are depicted in Figure 1. The attributes on the mahasiswa and karyawan entity shown in Figure 1 are the required attributes in the thesis examination timetabling system.

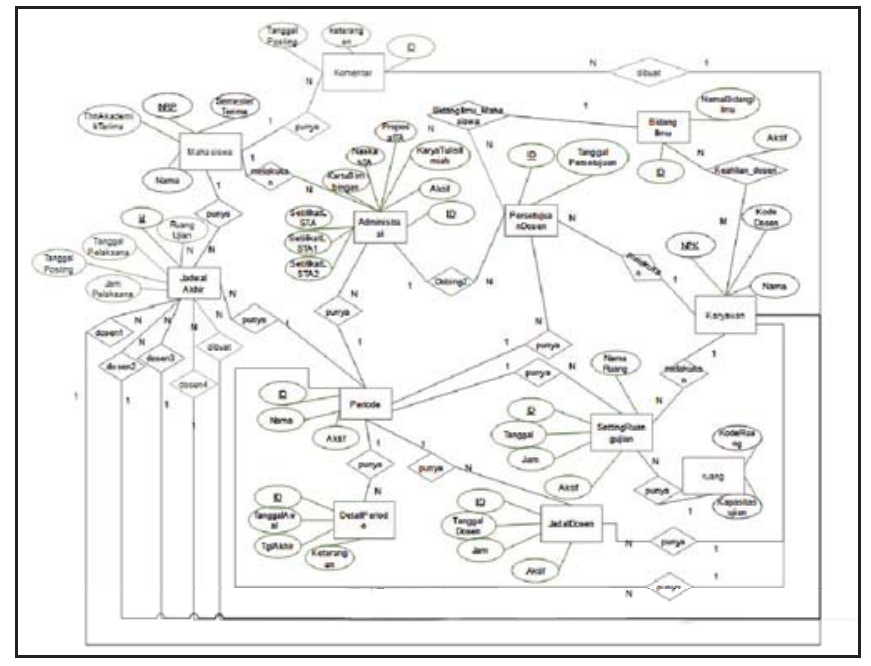

Fig. 1. The ERD of thesis examination timetabling system

Periode and DetailPeriode entities are used to store data during the period of thesis exams examination, which includes the period of registration of thesis exam preparation (LSTA), LSTA period, registration and prerequisite file collection period, thesis examination period, and period of thesis revision in accordance with examiner input during thesis examination. JadwalAkhir entity is used to store the student thesis examination schedule conducted in the current active exam period and has been verified by the program coordinator. Students that are eligible to take the thesis examination are students who have received approval from the supervisors and meet all requirements. Approval from the supervisor is stored in the PersetujuanDosen entity and all administrative requirements of the student applying for the thesis exam are stored in the Administrasi entity.

The developed system will automatically attempt to determine which examiners can examine at specified exam time slots and have expertise according to the student thesis topic. The lecturer's time availability slot provided to test the thesis is stored in the entity of the JadwalDosen and expertise owned by each lecturer stored in the BidangIlmu entity. This entity is required for the scheduling time, the system will automatically as much as possible to find examiners who have expertise in accordance with the thesis topic. The room used for the thesis examination is stored in SettingRuangUjian entity. Finally, Komentar is used to store comments include criticisms and suggestions from students and responses from examiners.

\section{B. Implementation of Genetic Algorithm}

After the data design is completed, then the design process of the thesis examination timetabling is prepared. The process of the thesis exam timetabling starts from setting the thesis exam period and the room that can be used for the thesis exam by the administrator after getting information from the program coordinator. After the administrator has opened the thesis exam registration, the system will automatically notify by email to all students who are taking the thesis and to all the lecturers to fill the exam readiness form. 
Students who have finished their thesis can register for a thesis exam followed by uploading all the requested administrative requirements. When a student registers, the system will automatically check the student's tuition payments. If the student has not completed the tuition fee, then the system will automatically refuse the student registration. Furthermore, the system will send notifications to the corresponding supervisors if there are any registered students. The supervisor who gets a notification can approve or reject the students to take the thesis exam if the supervisor feels the student is not yet eligible for the exam. If the supervisor does not approve, then the system will send notification to the student. After the deadline for registration is reached, the administrator will check all the administrative requirements of the student who gets approval from his / her supervisor. Afterwards, the administrator will verify the student who meets the administrative requirements and the system will automatically send notifications to the student. Finally, the system will automatically generate thesis examination timetable with genetic algorithms. The program coordinator is authorized to make changes to the thesis exam schedule generated by the system if needed. The flow of the thesis examination process can be seen in Figure 2.

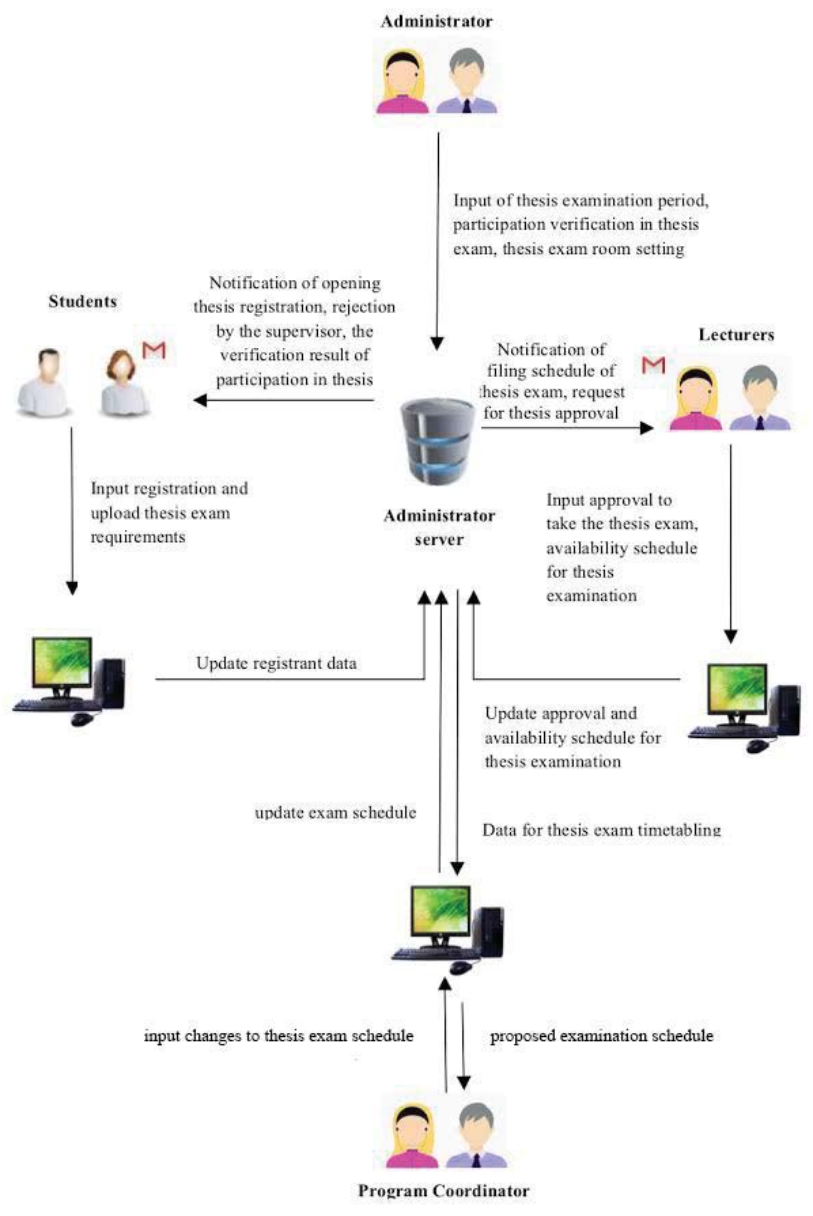

Fig. 2. Thesis examination timetabling flow

The thesis exam timetabling process begins with the exam time and room available according to the schedule of both supervisors. This is done by randomizing the exam readiness from the supervisors. The results of this randomization are combined with empty exam room dates and hours. Each slot formed represents a chromosome. Once the chromosome is formed, then the selection process is conducted. The selection process is done to determine which chromosome will be used as the parent. In the selection process, the system will give the fitness value on each chromosome. The amount of fitness value depends on the number of scheduled clashes. The clash was calculated from the unavailability of the exam room because it is already being used and the supervisor is already examine at the same time in another room. The greater the number of clashes that occur, the smaller the fitness value and the less likely the chromosome becomes the parent. The fitness value is calculated from the formula: $1 /($ (number of clashes)+1). The chromosome chosen to be the parent is 2 pieces of chromosome that has the highest fitness value. After the selection process is done, then do crossover between two parent chromosomes and produce new chromosomes. The new chromosome guarantees no clash in the use of exam room.

Mutation is done after the selection process. The mutation process is used to improve the fitness value of a gene on a chromosome. Changes in gene values can occur if the gene does not have the id of the exam room so that the system will look for another exam room id that has the same schedule as the availability schedule of the lecturer. Next, the determination of the chair and secretary of the thesis examiner is conducted. Selection of examiners who become chairman and secretary adjusted to the field of science of the thesis topic. After the candidate chairman and secretary selected, the system will match the availability schedule the selected candidate with the thesis examination schedule obtained from the previous process.

The final stage of this process is to determine the number of lecturers as examiners. Eligible candidates are selected based on the minimum number of exam schedules. After determining the chairman and secretary, the proposed thesis examination timetable is formed. Finally, the process of verifying the proposed thesis exam schedule formed by the program coordinator. A verified schedule can not be changed. The flow of thesis examination timetable preparation process can be seen in Figure 3 .

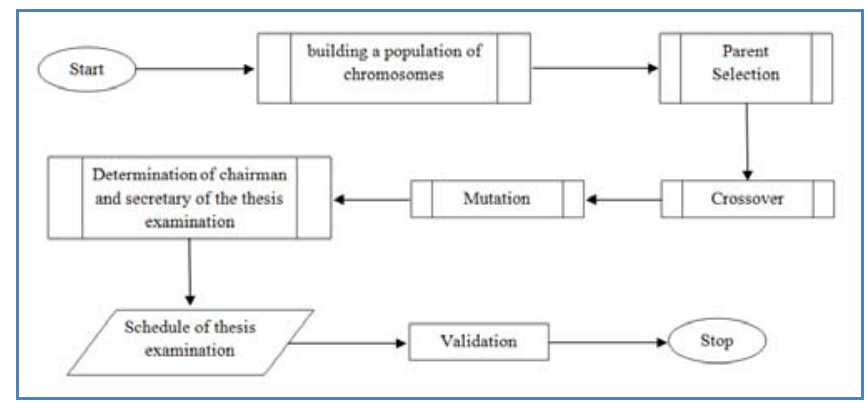

Fig. 3. The Formation Process of Thesis Examination Timetabling using Genetic Algorithm 


\section{RESULTS}

The design of data that has been made is implemented using phpmyadmin while the design of the process is webbased implemented using the laravel 5.2 framework. An example of the result of the implementation of the thesis exam period setting can be seen in Figure 4. On this page the administrator can set the deadline for each activity stage to take the thesis exam in accordance with the data from the program coordinator. While the example of the page to be filled with the availability of lecturers to examine the thesis can be seen in Figure 5.

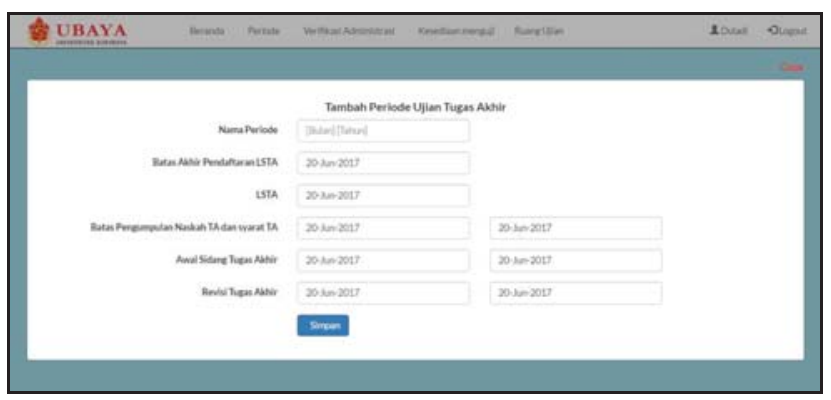

Fig. 4. The thesis exam period setting page

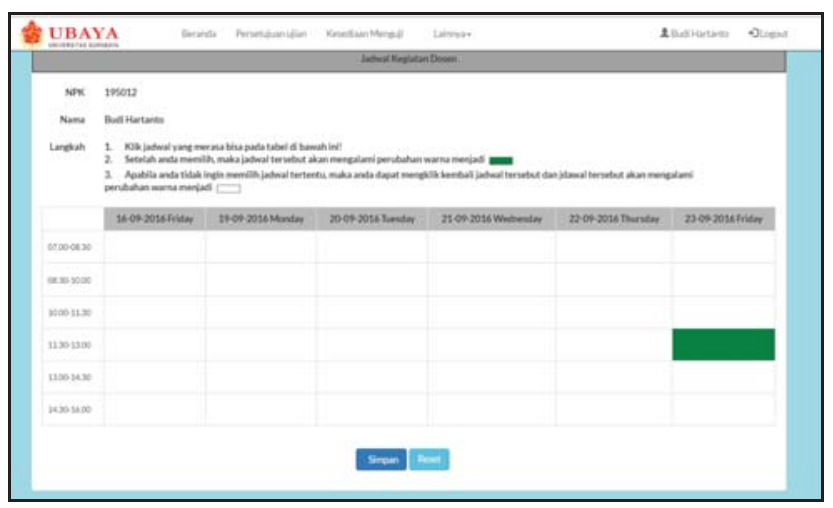

Fig. 5. The page to be filled with the availability of lecturers to examine the thesis

After the registration and file collection expires, the administrator will check the administrative requirements of students who have received approval from the supervisors. If all administrative requirements are met, the administrator will verify the student's data. An example of a verification page can be seen in Figure 6. While the sample timetable results can be seen in Figure 7. Figure 7 shows the schedule of 4 students generated by the thesis examination timetable system using genetic algorithm.

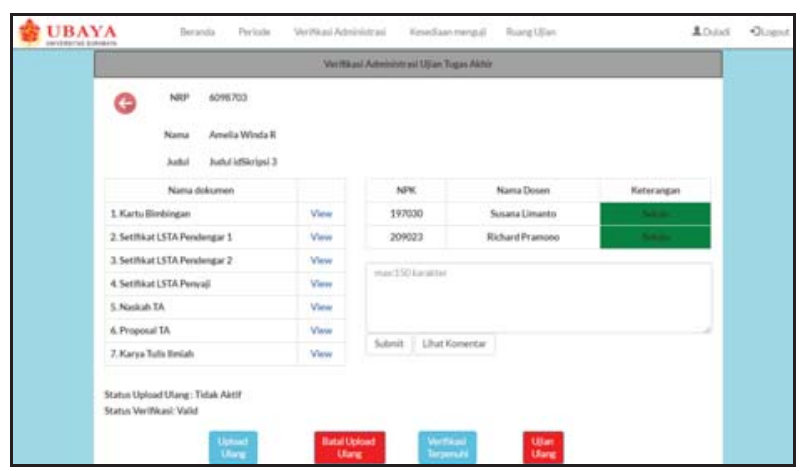

Fig. 6. Administrative Requirements Verification Page

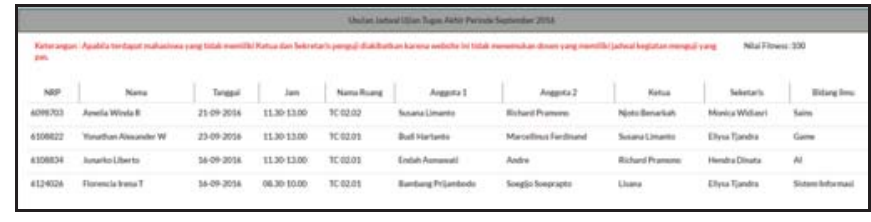

Fig. 7. Timetable result page

To ensure that the timetabling system of thesis examination that are made is in accordance with the needs of users, then validation is done. Validation is done in 2 ways, i.e comparing the results of theses scheduling exams ever done traditionally with scheduling results generated automatically from timetabling system and conducting interviews with user application respondents [9]. The first validation is done by comparing the result of traditional scheduling of thesis exam in Informatics Engineering Study Program September 2016 and November 2016 perios with result from web-based system. The results of traditional thesis timetabling in Informatics Engineering Program September 2016 period can be seen in Figure 8 and the results of traditional timetabling for November 2016 can be seen in Figure 9. While the timetabling results of the webbased system of September 2016 period can be seen in Figure 10 and the timetabling results of the application period of November 2016 can be seen in Figure 11.

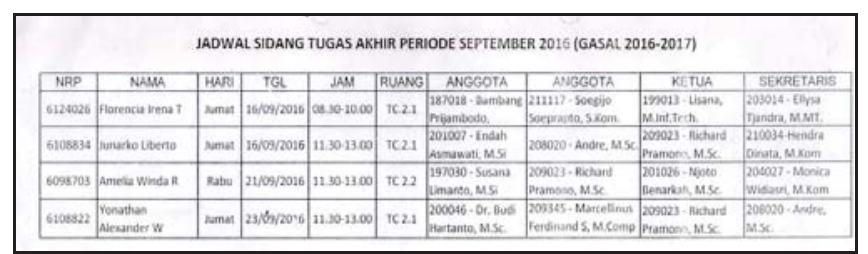

Fig. 8. Traditional Timetabling Results September 2016 Period

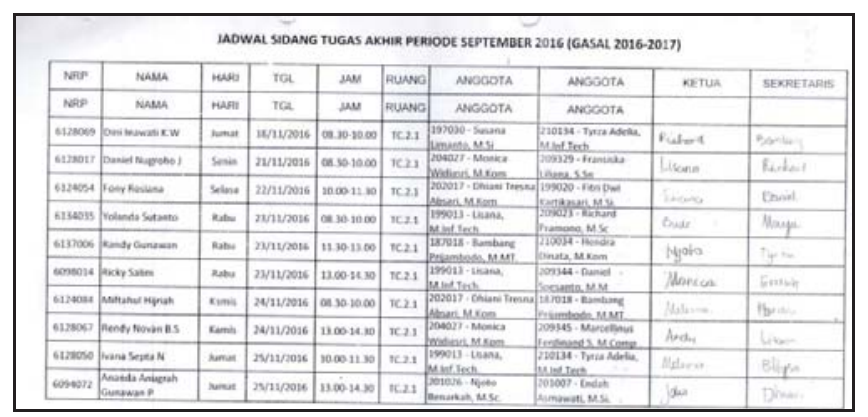

Fig. 9. Traditional Timetabling Results November 2016 Period

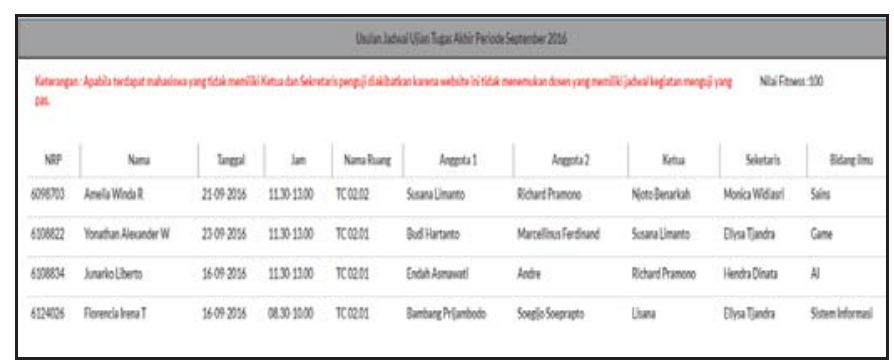

Fig. 10. Web-based Timetabling System Results September 2016 Period 


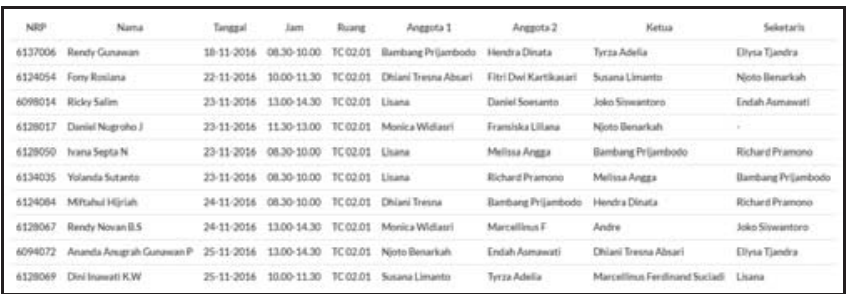

Fig. 11. Web-based Timetabling System Results November 2016 Period

The second validation is done by asking respondents to try the web-based system that has been made in accordance with their respective permissions and then interviewed related to the benefits and problems surrounding the execution of the thesis exam. Respondents consist of administrators, 10 students who will take the thesis exam, 2 program coordinators, and 5 lecturers. Particularly the program coordinator, in addition to attempting web-based systems and interviews, was also asked his opinion regarding the results of traditional scheduling and webbased systems because these two types of respondents usually handle traditional thesis exam timetabling. The validation result states that the students are greatly helped by the registration feature because they do not need to come directly to the department to register or request approval to take the exam to the supervisor, so they can save the time. The administrator is helped because there is no need to spread the exam readiness form one by one to the lecturers so that it can save costs, no need to schedule time and exam room so that it can save time and effort, and can immediately check the completeness of student requirements without needing to find the file first so it can save energy. Moreover, program coordinators are helped because no need to do the traditional timetabling. The lecturers are helped because they can fill in the form of schedule availability and give approval to take the thesis exam anywhere and anytime.

After comparing the results of traditional scheduling and web-based systems, the program coordinator stated that the scheduled results that have been developed already meet the timetabling criteria. In addition, this system it is very useful to avoid the occurrence of timetabling errors like the same 2 lecturers assigned to examine 2 different students at the same time or errors in taking into account the requirements of the Higher Education Service.

\section{CONCLUSIONS AND RECOMMENDATION}

A web-based thesis exams timetabling system was developed to help alleviate the task of the program coordinator in drafting a thesis exam timetable that usually takes a lot of time for having to do a lot of checking [9]. The web-based system developed can generate a thesis exam timetable proposal automatically by taking into account all the requirements set in the department of Informatics
Engineering Ubaya. The requirements set in the preparation of the thesis examination in Informatics Engineering Ubaya are the availability of room, the schedule provided by the lecturer, the minimum requirements for functional positions that must be possessed by the examining lecturer, the number of examiners, the suitability of the scientific field of examiners with the thesis topic of the students tested and the equalization of the number of student being examined for every lecturer.

For students, the application is useful to improve the efficiency of time in the process of submission to take the thesis exam. Students do not need to come to the study program to seek supervisory approval, to submit the thesis exam requirements file, or to see announcements related to thesis exam timetable. In addition, the application is also useful for administrators to improve the efficiency of time and energy, because they no longer need to distribute lecturers' exam readiness form to each lecturer, no need to schedule time and exam room, and can directly check the completeness of the student requirements file without the need to search the file. The lecturers are also helped because there is no need to be pursued by students who want to get approval for thesis exams and can fill out the lecturers' exam readiness form and give their approval to take the thesis exam anywhere and anytime. Therefore, it can be concluded that the system developed can improve the efficiency of time, effort, and cost from various parties. For the future, applications can be developed in the direction of mobile so that it suits the current conditions, in which almost everyone has mobile devices.

\section{REFERENCES}

[1] Rector's Secretariat, "Rector's Regulation No.183 of 2018", unpublished.

[2] Rector's Secretariat, 'Universitas Surabaya Rector's Regulation No. 299 of 2018, Thesis Supervisor and Examiner Standard at Universitas Surabaya", unpublished.

[3] R. K. Baker and Trietsch, "Principles of Sequencing and Schedulling," United States of America: John Wiley and Sons, Inc.

[4] J. C. Wibawa and M. R. Fachrizal, "Rancang Bangun Aplikasi Penjadwalan Bimbingan PKL dan Skripsi Berbasis Android" in Jurnal Teknik Informatika dan Sistem Informasi, 2017, pp.150-168

[5] A. D. Cahyo, I. F. Rozi, and R. Ariyanto, "Optimasi Penjadwalan Sidang Skripsi Jurusan Teknik Informatika" in Jurnal Informatika Polinema, 2015, pp.43-48

[6] I. P. G. Budayasa and A. M. Dirgayusari, "Optimasi Penjadwalan Seminar dan Sidang Tugas Akhir pada Sistem Informasi Tugas Akhir di STMIK STIKOM Indonesia," in Jurnal Ilmu Komputer dan Sains Terapan, 2017, pp.96-105

[7] Rector's Secretariat, "Rector's Regulation No.222 of 2018", unpublished.

[8] T. T. B. Huynh, Q. D. Pham, and D. D. Pham, "Genetic algorithm for solving the master thesis timetabling problem with multiple objectives", in 2012 Conference on Technologies and Applications of Artificial Intelligence, IEEE, pp.74-79

[9] W. S. Widjaya, "Penggunaan Algoritma Genetika untuk Sistem Penjadwalan Ujian Tugas Akhir Jurusan Teknik Informatika Universitas Surabaya, " Jurusan Teknik Informatika - Fakultas Teknik - Universitas Surabaya. 


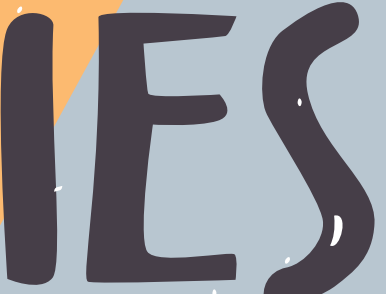

INTERRATIONAL ELECTRONICS SYMPOSIUM BALI $\cdot 2018$ $\mathcal{1}$

Energy Sustainovation and Techno-Intelligence for Realizing Industrial Revo'ution 4.0.
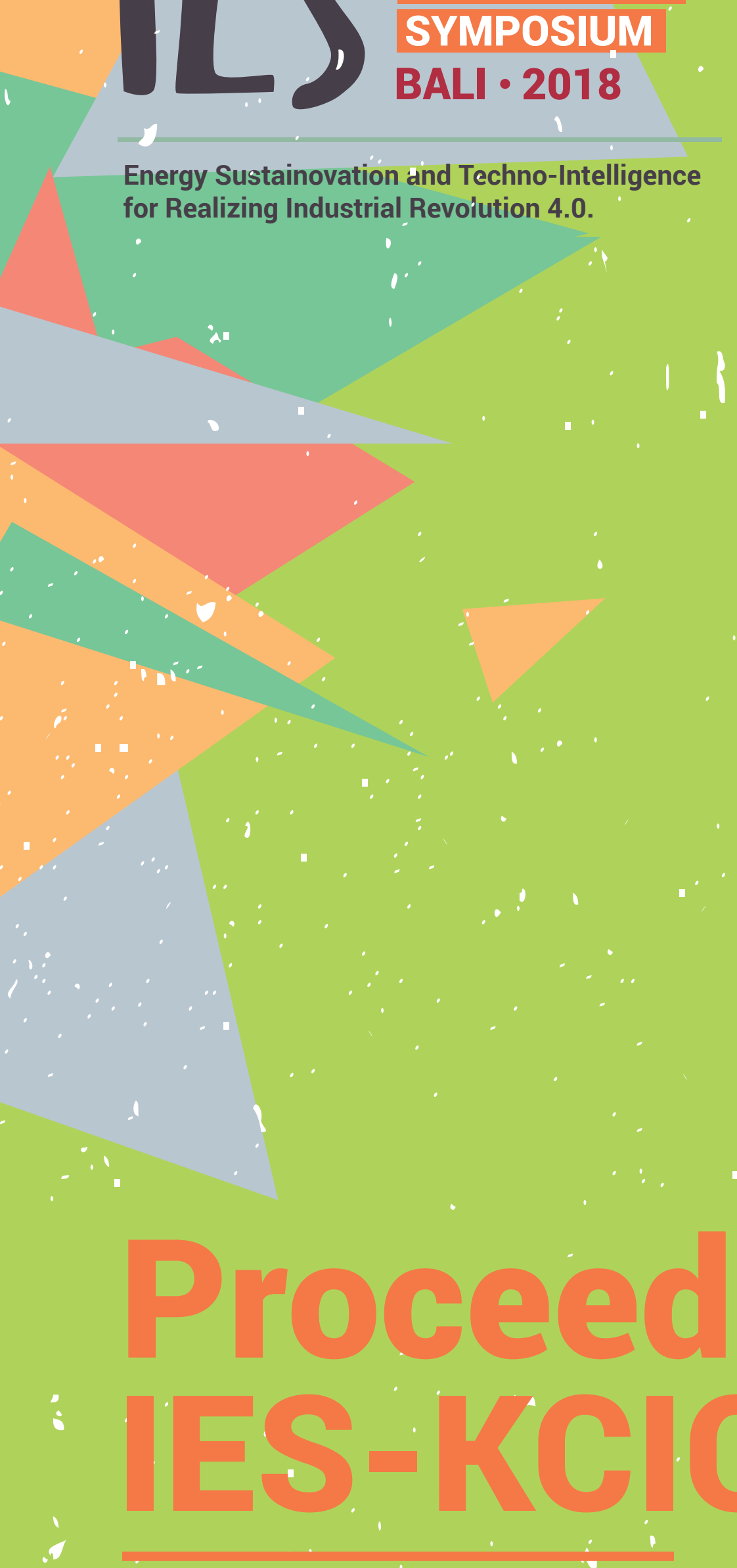

$\because$

.




\section{International Electronics Symposium on Knowledge Creation and Intelligent Computing (IES-KCIC) Committee}

\section{Host Organizer}

Politeknik Elektronika Negeri Surabaya (PENS)

\section{Co-Host Organizer}

IEEE INDONESIA SECTION

\section{General Chairman}

Tri Budi Santoso (PENS, Indonesia)

\section{Advisory Committee}

Zainal Arief (PENS, Indonesia)

Yasushi Kiyoki (Keio University, J apan)

Dadet Pramadihanto (PENS, Indonesia)

Fitri Yuli Zulkifli (IEEE Indonesia)

Titon Dutono (PENS, Indonesia)

\section{Program Chairs}

Ali Ridho Barakbah (PENS, Indonesia)

Tri Harsono (PENS, Indonesia)

Anang Tjahjono (PENS, Indonesia)

Shiori Sasaki (Keio University, J apan)

Agnes Irwanti (IEEE Indonesia)

\section{Publicity Chair}

Amang Sudarsono (PENS, Indonesia)

Akhmad Alimudin (PENS, Indonesia)

Widi Sarinastiti (PENS, Indonesia)

\section{Publication Chair}

Udin Harun Al Rasyid (PENS, Indonesia)

Ahmad Zainudin (PENS, Indonesia)

Farid Dwi Murdianto (PENS, Indonesia)

Fahim Nur Cahya Bagar (PENS, Indonesia)

Martianda Erste Anggraeni (PENS, Indonesia)

Ida Anisah (PENS, Indonesia)

\section{Workshop Chair}

Eko Henfri Binugroho (PENS, Indonesia)

Akhmad Subhan Kh. (PENS, Indonesia)

Treasurer Chair

Ita Zoeriah (PENS, Indonesia)

Anggi Puspitasari (PENS, Indonesia) 
International Special Issue Journal Chair

Prima Kristalina (PENS, Indonesia)

\section{Local Arrangement Chair}

Dwi Kurnia Basuki (PENS, Indonesia)

Kholid Fathoni (PENS, Indonesia)

Widi Sarinastiti (PENS, Indonesia)

Dias Agata (PENS, Indonesia)

Didik Santoso (PENS, Indonesia)

Gentur Pamungkas P. W. (PENS, Indonesia)

\section{Technical Program Committee}

Achmad Basuki, Politeknik Elektronika Negeri Surabaya (PENS), Indonesia Afrida Helen, Politeknik Elektronika Negeri Surabaya (PENS), Indonesia Agus Indra G., Politeknik Elektronika Negeri Surabaya (PENS), Indonesia Ali Ridho Barakbah, Politeknik Elektronika Negeri Surabaya (PENS), Indonesia Alrijadjis, Politeknik Elektronika Negeri Surabaya (PENS), Indonesia Amang Sudarsono, Politeknik Elektronika Negeri Surabaya (PENS), Indonesia Anang Tjahjono, Politeknik Elektronika Negeri Surabaya (PENS), Indonesia Asako Uraki, Keio University, J apan

Bambang Sumantri, Politeknik Elektronika Negeri Surabaya (PENS), Indonesia Bima Sena Bayu D., Politeknik Elektronika Negeri Surabaya (PENS), Indonesia Chawan Koopipat, Chulalongkorn University, Thailand

Dadet Pramadihanto, Politeknik Elektronika Negeri Surabaya (PENS), Indonesia

Dedid Happyanto, Politeknik Elektronika Negeri Surabaya (PENS), Indonesia Eko Henfri B., Politeknik Elektronika Negeri Surabaya (PENS), Indonesia I Gede Puja A., Politeknik Elektronika Negeri Surabaya (PENS), Indonesia Iwan Syarif, Politeknik Elektronika Negeri Surabaya (PENS), Indonesia Kanako Morita, Forestry and Forest Products Research Institute, J apan Kosuke Takano, Kanagawa Institute of Technology, J apan M. Udin Harun A., Politeknik Elektronika Negeri Surabaya (PENS), Indonesia Mehmet Güzel, Ankara University, Turkey M. Agus Zainuddin, Politeknik Elektronika Negeri Surabaya (PENS), Indonesia Naofumi Yoshida, Komazawa University, J apan Novie Windarko, Politeknik Elektronika Negeri Surabaya (PENS), Indonesia Panus NattharithNaresuan, University, Thailand

Paramin Neranon, Prince of Songkla University, Thailand

Petri Rantanen Tampere University of Technology, Finland

Prima Kristalina, Politeknik Elektronika Negeri Surabaya (PENS), Indonesia Raden Sanggar D., Politeknik Elektronika Negeri Surabaya (PENS), Indonesia Riyanto Sigit, Politeknik Elektronika Negeri Surabaya (PENS), Indonesia Rusminto Widodo, Politeknik Elektronika Negeri Surabaya (PENS), Indonesia Shiori Sasaki, Keio University, J apan

Son Kuswadi, Politeknik Elektronika Negeri Surabaya (PENS), Indonesia Sritrusta Sukaridhoto, Politeknik Elektronika Negeri Surabaya (PENS), Indonesia 
Technical Program Committee (cont'd)

Tatjana Endrjukaite, SIA Klarus Ltd., Latvia

Tessy Badriyah, Politeknik Elektronika Negeri Surabaya (PENS), Indonesia

Tri Budi Santoso, Politeknik Elektronika Negeri Surabaya (PENS), Indonesia

Tri Harsono, Politeknik Elektronika Negeri Surabaya (PENS), Indonesia

Wahjoe Sesulihatien, Politeknik Elektronika Negeri Surabaya (PENS),

Indonesia

Yasuhiro Hayashi, Keio University \& Graduate School of Media and

Governance, Japan 
2018 International Electronics Symposium on Knowledge Creation and Intelligent Computing (IES-KCIC) Committee ........................ iv

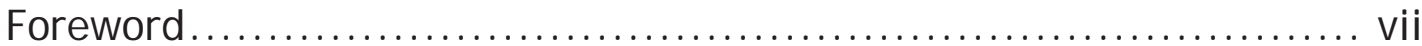

Welcome Message from General Chair of IES-KCIC $2018 \ldots \ldots \ldots \ldots \ldots$ ix

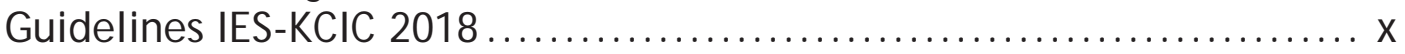

Maps and Location for IES-KCIC $2018 \ldots \ldots \ldots \ldots \ldots \ldots \ldots \ldots \ldots \ldots \ldots \ldots \ldots \ldots \ldots$

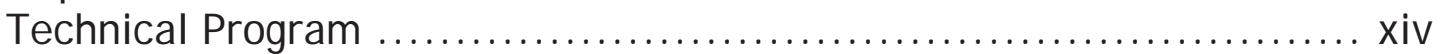

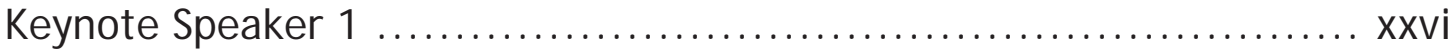

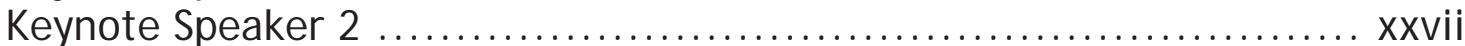

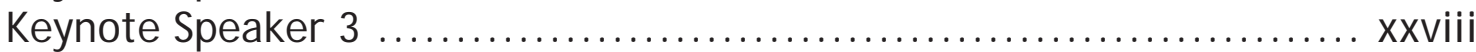

Workshop 1 : Wireless Sensor Network ........................... xxx

Workshop 2: Asia Artificial Intelligence Institute (AAll) ................ xxxi 


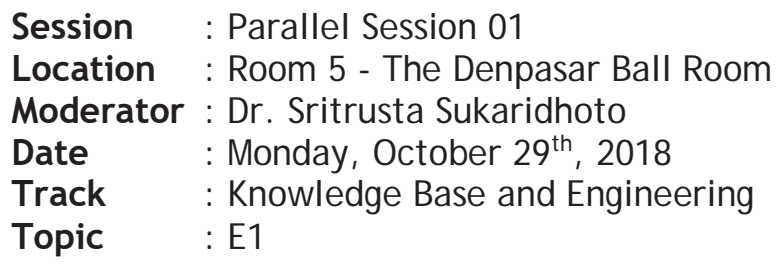

\begin{tabular}{|c|c|c|c|}
\hline Time & ID Paper & Title & Author(s) \\
\hline $11.00-11.15$ & 1570477748 & $\begin{array}{l}\text { Physical Exercise for The Elderly } \\
\text { People using Kinect Technology }\end{array}$ & \begin{tabular}{|c|} 
Intan Irnanda (Electronic \\
Engineering Polytechnic Institute \\
of Surabaya, Indonesia); Achmad \\
Basuki (Politeknik Elektronika \\
Negeri Surabaya, Indonesia); \\
Fadilah Fahrul Hardiansyah \\
(Electronic Engineering Polytechnic \\
Institute of Surabaya, Indonesia) \\
\end{tabular} \\
\hline $11.15-11.30$ & 1570477750 & $\begin{array}{l}\text { Thesis Examination Timetabling } \\
\text { using Genetic Algorithm }\end{array}$ & \begin{tabular}{|c|} 
Susana Limanto (University of \\
Surabaya, Indonesia); Tyrza Adelia \\
(Universitas Surabaya, Indonesia); \\
Njoto Benarkah (Universities \\
Surabaya, Indonesia) \\
\end{tabular} \\
\hline $11.30-11.45$ & 1570483453 & $\begin{array}{l}\text { Integrated Robotics } \\
\text { Architecture with Kansei } \\
\text { Computing: Proposal and Initial } \\
\text { Prototype }\end{array}$ & $\begin{array}{c}\text { Yoshiko Itabashi (Keio University, } \\
\text { Keio Research Institute at SFC, } \\
\text { J apan); Yasushi Kiyoki (Keio } \\
\text { University, J apan) }\end{array}$ \\
\hline $11.45-12.00$ & 1570483861 & $\begin{array}{l}\text { Message Passing Support for } \\
\text { FLoW Microkernel }\end{array}$ & \begin{tabular}{|l|} 
Ivan Pandu Setiawan and Sritrusta \\
Sukaridhoto (Politeknik Elektronika \\
Negeri Surabaya, Indonesia); Dadet \\
Pramadihanto (PENS, Indonesia) \\
\end{tabular} \\
\hline $12.00-12.15$ & 1570483944 & $\begin{array}{l}\text { Development and Performance } \\
\text { Testing of FLoWRTOS with } \\
\text { Random Case: } 3 \text { Main Processes } \\
\text { on The Head System of T-FLoW } \\
\text { Robot }\end{array}$ & \begin{tabular}{|c|} 
Agung Pambudi (Politeknik \\
Elektronika Negeri Surabaya, EEPIS \\
Robotics Research Center); Dadet \\
Pramadihanto (PENS, Indonesia); \\
Dimas Pristovani Riananda \\
(Electronics Engineering \\
Polytechnic Institute of Surabaya \\
(EEPIS), Indonesia) \\
\end{tabular} \\
\hline
\end{tabular}




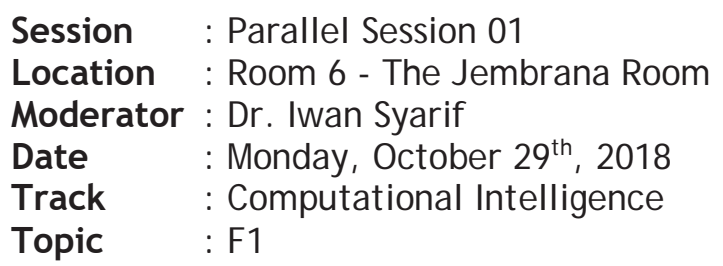

\begin{tabular}{|c|c|c|c|}
\hline Time & ID Paper & Title & Author(s) \\
\hline $11.00-11.15$ & 1570477153 & $\begin{array}{l}\text { Estimation of A 3D Object Pose } \\
\text { Using The Single Flexible } \\
\text { Template }\end{array}$ & $\begin{array}{c}\text { Dewi Mutiara Sari (Electronic } \\
\text { Engineering Polytechnic Institute } \\
\text { of Surabaya, Indonesia); Vina } \\
\text { Wahyuni Eka Putranti (MJ IIT - } \\
\text { Universiti Teknologi Malaysia, } \\
\text { Malaysia) }\end{array}$ \\
\hline $11.15-11.30$ & 1570477452 & $\begin{array}{l}\text { A Physical and Emotional Distance } \\
\text { Calculation Method for Searching } \\
\text { and Recommending Sightseeing } \\
\text { Spots in Tour-Semantic Space }\end{array}$ & $\begin{array}{l}\text { Kaito Kikuhara and Yasushi Kiyoki } \\
\text { (Keio University, J apan) }\end{array}$ \\
\hline $11.30-11.45$ & 1570477550 & $\begin{array}{l}\text { Pattern Recognition based on } \\
\text { Probabilistic Neural Network for } \\
\text { Motorcycle Oil Fault Diagnosis }\end{array}$ & $\begin{array}{l}\text { Faisa Lailiyul Mutho'affifah, } \\
\text { Zaqiatud Darojah and Endah } \\
\text { Suryawati Ningrum (Politeknik } \\
\text { Elektronika Negeri Surabaya, } \\
\text { Indonesia) }\end{array}$ \\
\hline $11.45-12.00$ & 1570481261 & $\begin{array}{l}\text { Neural Networks Algorithm to } \\
\text { Inquire Previous Preeclampsia } \\
\text { Factors in Women with Chronic } \\
\text { Hypertension During Pregnancy in } \\
\text { Childbirth Process }\end{array}$ & $\begin{array}{c}\text { Muhlis Tahir (Politeknik } \\
\text { Elektronika Negeri Surabaya, } \\
\text { Indonesia); Tessy Badriyah } \\
\text { (Electronic Engineering } \\
\text { Polytechnic Institute of } \\
\text { Surabaya, Indonesia); Iwan Syarif } \\
\text { (Politeknik Elektronika Negeri } \\
\text { Surabaya (PENS), Indonesia) }\end{array}$ \\
\hline $12.00-12.15$ & 1570482628 & $\begin{array}{l}\text { Evaluation of Scholarly } \\
\text { Performance Student Using Multi- } \\
\text { Criteria Decision-Making with } \\
\text { Objective Weight }\end{array}$ & $\begin{array}{l}\text { Masna Wati and Niken Novirasari } \\
\text { (Universitas Mulawarman, } \\
\text { Indonesia); Herman Pakpahan } \\
\text { (University of Mulawarman, } \\
\text { Faculty of Computer Science and } \\
\text { Information Technology (CSIT), } \\
\text { Indonesia) }\end{array}$ \\
\hline
\end{tabular}




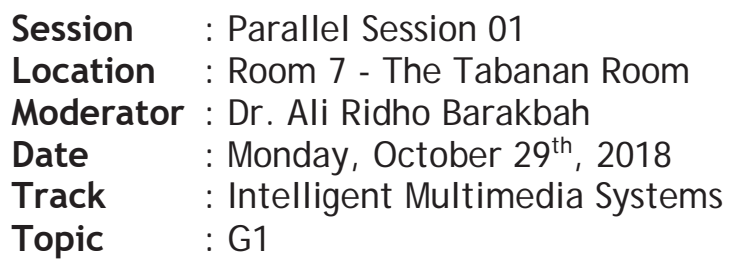

\begin{tabular}{|c|c|l|c|}
\hline Time & ID Paper & \multicolumn{1}{|c|}{ Title } & \multicolumn{1}{c|}{ Author(s) } \\
\hline $11.00-11.15$ & 1570483063 & $\begin{array}{l}\text { 3D Inventory Information } \\
\text { System Game Technology } \\
\text { Laboratory Using Structure } \\
\text { Sensor }\end{array}$ & $\begin{array}{c}\text { Agus Prastyo and Mohamad Safrodin } \\
\text { (PENS, Indonesia); Artiarini } \\
\text { Nurindiyani (Lecturer, Politeknik } \\
\text { Elektronika Negeri Surabaya, } \\
\text { Indonesia) }\end{array}$ \\
\hline $11.15-11.30$ & 1570483463 & $\begin{array}{l}\text { Gesture 3D Modeling for } \\
\text { Traditional J avanese Dance }\end{array}$ & $\begin{array}{c}\text { Artiarini Nurindiyani (Lecturer, } \\
\text { Politeknik Elektronika Negeri } \\
\text { Surabaya, Indonesia); Fardani Annisa } \\
\text { Damastuti (Politeknik Elektronika } \\
\text { Negeri Surabaya, Indonesia) }\end{array}$ \\
\hline $11.30-11.45$ & 1570483782 & $\begin{array}{l}\text { Lutfiyatul Anas and Nana } \\
\text { Eystem For Selecting Fashion } \\
\text { Item Based on Like and Dislike } \\
\text { Expression }\end{array}$ & $\begin{array}{l}\text { Implementation of Facial } \\
\text { Negeri Surabaya, Indonesia); Achmad } \\
\text { Basuki (Politeknik Elektronika Negeri } \\
\text { Surabaya, Indonesia) }\end{array}$ \\
\hline $11.45-12.00$ & 1570486246 & $\begin{array}{l}\text { First Person Shooter VR based } \\
\text { Game On 10 November 1945 } \\
\text { With Motion Controller }\end{array}$ & $\begin{array}{c}\text { David Abdillah, Kholid Fathoni and } \\
\text { Fahim Bagar (Politeknik Elektronika } \\
\text { Negeri Surabaya, Indonesia) }\end{array}$ \\
\hline $12.00-12.15$ & 1570483821 & $\begin{array}{l}\text { A Mental Health Database } \\
\text { Creation Method with 2-Phase } \\
\text { Correlation Computing }\end{array}$ & $\begin{array}{c}\text { Venera Raneva (Keio University, } \\
\text { Faculty of Media and Governance, } \\
\text { Japan); Yasushi Kiyoki (Keio } \\
\text { University, J apan) }\end{array}$ \\
\hline
\end{tabular}




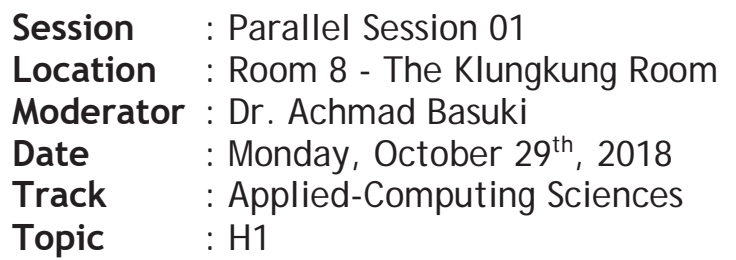

\begin{tabular}{|c|c|c|c|}
\hline Time & ID Paper & Title & Author(s) \\
\hline $11.00-11.15$ & 1570487337 & $\begin{array}{l}\text { A Composition-Based Image } \\
\text { Retrieval Method for } \\
\text { Environment-Visualization } \\
\text { with Images and Spatio- } \\
\text { Temporal Information }\end{array}$ & $\begin{array}{c}\text { Yuka Toyoshima (Keio University, } \\
\text { Japan); Yasuhiro Hayashi (Musashino } \\
\text { University, Japan); Yasushi Kiyoki (Keio } \\
\text { University, J apan) }\end{array}$ \\
\hline $11.15-11.30$ & 1570489021 & $\begin{array}{l}\text { Facial Expression } \\
\text { Recognition System for } \\
\text { Analysis of Facial Expression } \\
\text { Changes When Singing }\end{array}$ & $\begin{array}{c}\text { Aditya Wardana (PENS, Indonesia); Nana } \\
\text { Ramadijanti (Politeknik Elektronika } \\
\text { Negeri Surabaya, Indonesia); Achmad } \\
\text { Basuki (Politeknik Elektronika Negeri } \\
\text { Surabaya, Indonesia) } \\
\end{array}$ \\
\hline $11.30-11.45$ & 1570482379 & $\begin{array}{l}\text { Secure Attribute-Based } \\
\text { Encryption With Access } \\
\text { Control to Data Medical } \\
\text { Records }\end{array}$ & $\begin{array}{c}\text { Novi Fitri (Politeknik Elektronika Negeri } \\
\text { Surabaya, Indonesia); M. Udin Harun Al } \\
\text { Rasyid and Amang Sudarsono (Politeknik } \\
\text { Elektronika Negeri Surabaya (PENS), } \\
\text { Indonesia) } \\
\end{array}$ \\
\hline $11.45-12.00$ & 1570483258 & $\begin{array}{l}\text { A Context-based Knowledge } \\
\text { Acquisition System for } \\
\text { Understanding Relations } \\
\text { between Endangered } \\
\text { Species and Daily } \\
\text { Phenomena }\end{array}$ & $\begin{array}{l}\text { Sari Inoue, Shiori Sasaki and Yasushi } \\
\text { Kiyoki (Keio University, J apan) }\end{array}$ \\
\hline $12.00-12.15$ & 1570483558 & $\begin{array}{l}\text { Application For } \\
\text { Rehabilitation Of Fine } \\
\text { Movement On Hand For } \\
\text { Post-Stroke Patients Using } \\
\text { Myo Armband }\end{array}$ & $\begin{array}{c}\text { Muhammad Widodo and Moh. Zikky } \\
\text { (Politeknik Elektronika Negeri Surabaya, } \\
\text { Indonesia); Artiarini Nurindiyani } \\
\text { (Lecturer, Politeknik Elektronika Negeri } \\
\text { Surabaya, Indonesia) }\end{array}$ \\
\hline
\end{tabular}




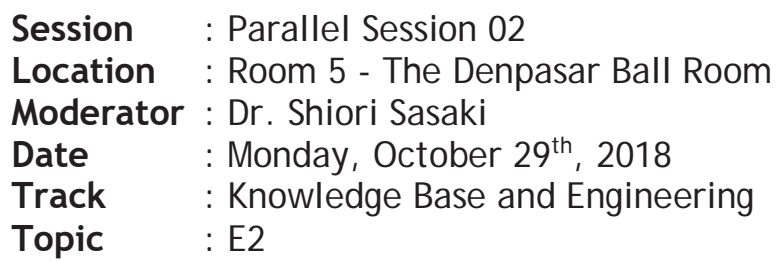

\begin{tabular}{|c|c|c|c|}
\hline Time & ID Paper & Title & Author(s) \\
\hline $16.00-16.15$ & 1570483819 & $\begin{array}{l}\text { A Regional-Diversity- } \\
\text { Corresponding Real Estate } \\
\text { Information Search \& } \\
\text { Evaluation System }\end{array}$ & $\begin{array}{l}\text { Haruki Honda and Shiori Sasaki (Keio } \\
\text { University, J apan); Yasuhiro Hayashi } \\
\text { (Keio University, Graduate School of } \\
\text { Media and Governance, J apan); } \\
\text { Yasushi Kiyoki (Keio University, J Japan) }\end{array}$ \\
\hline $16.15-16.30$ & 1570486596 & $\begin{array}{l}\text { Making Short Movie using 3D } \\
\text { Professional Camera }\end{array}$ & $\begin{array}{l}\text { Hestiasari Rante and Fardani Annisa } \\
\text { Damastuti (Politeknik Elektronika } \\
\text { Negeri Surabaya, Indonesia); Dadet } \\
\text { Pramadihanto (PENS, Indonesia); } \\
\text { Muhammad Ali Akbar (Politeknik } \\
\text { Elektronika Negeri Surabaya, } \\
\text { Indonesia) }\end{array}$ \\
\hline $16.30-16.45$ & 1570486819 & $\begin{array}{l}\text { A Multi-dimensional } \\
\text { Visualization Method for } \\
\text { Disaster Analysis on 5D } \\
\text { World Map System }\end{array}$ & $\begin{array}{c}\text { Asako Uraki, Shiori Sasaki and Yasushi } \\
\text { Kiyoki (Keio University, J apan) }\end{array}$ \\
\hline $16.45-17.00$ & 1570487204 & $\begin{array}{l}\text { Identification of Poisonous } \\
\text { Fungi Basidiomycota Macro } \\
\text { Based on Mobile Device } \\
\text { Using Neural Network }\end{array}$ & $\begin{array}{c}\text { Meilani Wulandari (Politeknik } \\
\text { Elektronika Negeri Surabaya, } \\
\text { Indonesia); Entin Martiana } \\
\text { Kusumaningtyas (Politeknik Elektronika } \\
\text { Negeri Surabaya(PENS)-Indonesia, } \\
\text { Indonesia); Ali Ridho Barakbah } \\
\text { (Politeknik Elektronika Negeri } \\
\text { Surabaya, Indonesia) }\end{array}$ \\
\hline $17.00-17.15$ & 1570487308 & $\begin{array}{l}\text { Heart Abnormalities } \\
\text { Detection Through Iris Based } \\
\text { on Mobile }\end{array}$ & $\begin{array}{c}\text { Febriana D. Kusuma (Politeknik } \\
\text { Elektronika Negeri Surabaya, } \\
\text { Indonesia); Entin Martiana } \\
\text { Kusumaningtyas (Politeknik Elektronika } \\
\text { Negeri Surabaya(PENS)-Indonesia, } \\
\text { Indonesia); Ali Ridho Barakbah } \\
\text { (Politeknik Elektronika Negeri } \\
\text { Surabaya, Indonesia) }\end{array}$ \\
\hline
\end{tabular}




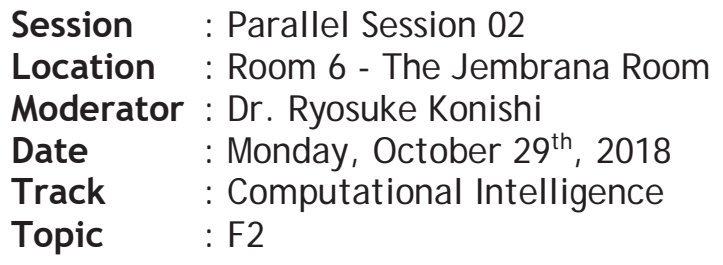

\begin{tabular}{|c|c|c|c|}
\hline Time & ID Paper & Title & Author(s) \\
\hline 16.00-16. 15 & 1570483257 & $\begin{array}{l}\text { Indonesian Vehicle License } \\
\text { Plate Number Detection using } \\
\text { Deep Convolutional Neural } \\
\text { Network }\end{array}$ & $\begin{array}{c}\text { Hasan Imaduddin, Muhamad } \\
\text { Khoirul Anwar and Muhammad } \\
\text { Ilham Perdana (Politeknik } \\
\text { Elektronika Negeri Surabaya, } \\
\text { Indonesia); Indra Adj i Sulistijono } \\
\text { (Politeknik Elektronika Negeri } \\
\text { Surabaya (PENS), Electronics } \\
\text { Engineering Polytechnic Institute } \\
\text { of Surabaya (EEPIS), Indonesia); } \\
\text { Anhar Risnumawan (Politeknik } \\
\text { Elektronika Negeri Surabaya, } \\
\text { Indonesia) }\end{array}$ \\
\hline $16.15-16.30$ & 1570483543 & $\begin{array}{l}\text { Estimating Adaptive Individual } \\
\text { Interests and Needs Based on } \\
\text { Online Local Variational } \\
\text { Inference for a Logistic } \\
\text { Regression Mixture Model }\end{array}$ & $\begin{array}{c}\text { Ryosuke Konishi and Fumito } \\
\text { Nakamura (Generic Solution } \\
\text { Corporation, Japan); Yasushi Kiyoki } \\
\text { (Keio University, J apan) }\end{array}$ \\
\hline $16.30-16.45$ & 1570483565 & $\begin{array}{l}\text { Automatic Breast Tumor } \\
\text { Segmentation Using Hierarchical } \\
\text { K-means on Mammogram }\end{array}$ & $\begin{array}{c}\text { Nana Ramadijanti, Farida Husna } \\
\text { and Ali Ridho Barakbah (Politeknik } \\
\text { Elektronika Negeri Surabaya, } \\
\text { Indonesia) }\end{array}$ \\
\hline $16.45-17.00$ & 1570483902 & $\begin{array}{l}\text { Semantic Video } \\
\text { Recommendation System Based } \\
\text { on Video Viewers Impression } \\
\text { From Emotion Detection }\end{array}$ & $\begin{array}{c}\text { Darari Nur Amali and Ali Ridho } \\
\text { Barakbah (Politeknik Elektronika } \\
\text { Negeri Surabaya, Indonesia); Adnan } \\
\text { Rachmat Anom Besari (Politeknik } \\
\text { Elektronika Negeri Surabaya } \\
\text { (PENS), Electronic Engineering } \\
\text { Polytechnic Institute of Surabaya } \\
\text { (EEPIS), Indonesia); Dias Agata } \\
\text { (Poiliteknik Elektronika Negeri } \\
\text { Surabaya, Indonesia) }\end{array}$ \\
\hline $17.00-17.15$ & 1570483932 & $\begin{array}{l}\text { Synthesis of Neural Oscillator } \\
\text { based Dynamic Rhythmic } \\
\text { Generation in Quadruped Robot } \\
\text { Locomotion }\end{array}$ & $\begin{array}{c}\text { Azhar Aulia Saputra and Naoyuki } \\
\text { Kubota (Tokyo Metropolitan } \\
\text { University, J apan) }\end{array}$ \\
\hline
\end{tabular}




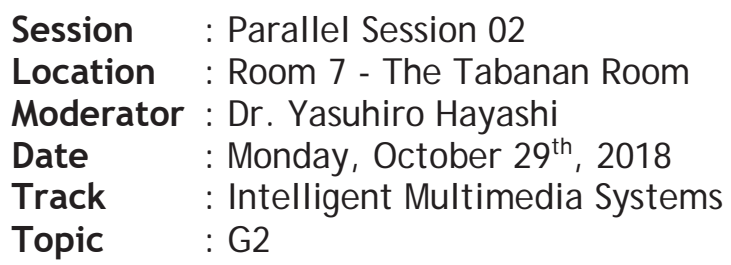

\begin{tabular}{|c|c|c|c|}
\hline Time & ID Paper & Title & Author(s) \\
\hline $16.00-16.15$ & 1570483904 & $\begin{array}{l}\text { Moving Object Velocity Detection } \\
\text { Based on Motion Blur on Photos } \\
\text { Using Gray Level }\end{array}$ & $\begin{array}{c}\text { Julio Dwicahya and Nana } \\
\text { Ramadijanti (Politeknik } \\
\text { Elektronika Negeri Surabaya, } \\
\text { Indonesia); Achmad Basuki } \\
\text { (Politeknik Elektronika Negeri } \\
\text { Surabaya, Indonesia) } \\
\end{array}$ \\
\hline 16. $15-16.30$ & 1570483938 & $\begin{array}{l}\text { Mobile Visual Programming Apps } \\
\text { for Internet of Things Applications } \\
\text { based on Raspberry Pi } 3 \text { Platform }\end{array}$ & $\begin{array}{c}\text { Ricky Setiawan (Politeknik } \\
\text { Elektronika Negeri Surabaya, } \\
\text { Indonesia); Adnan Rachmat Anom } \\
\text { Besari (Politeknik Elektronika } \\
\text { Negeri Surabaya (PENS), } \\
\text { Electronic Engineering } \\
\text { Polytechnic Institute of Surabaya } \\
\text { (EEPIS), Indonesia); Iwan } \\
\text { Kurnianto Wibowo (Electronic } \\
\text { Engineering Polytechnic Institute } \\
\text { of Surabaya, Indonesia); Muh } \\
\text { Rifqi Rizqullah (Politeknik } \\
\text { Elektronika Negeri Surabaya, } \\
\text { Indonesia); Dias Agata } \\
\text { (Poiliteknik Elektronika Negeri } \\
\text { Surabaya, Indonesia) }\end{array}$ \\
\hline $16.30-16.45$ & 1570485245 & $\begin{array}{l}\text { J amarat Ritual Simulation with } \\
\text { Myo Armband for Precise Throws } \\
\text { Speed }\end{array}$ & $\begin{array}{c}\text { Iqbal Sabilirrasyad (University of } \\
\text { Electronic Engineering } \\
\text { Polytechnic Institute of } \\
\text { Surabaya, Indonesia); Moh. Zikky } \\
\text { and Rizky Yuniar Hakkun } \\
\text { (Politeknik Elektronika Negeri } \\
\text { Surabaya, Indonesia) }\end{array}$ \\
\hline $16.45-17.00$ & 1570487286 & $\begin{array}{l}\text { 3D Visualization and Emerge 3D } \\
\text { Model Human Body of J avanese } \\
\text { Dance }\end{array}$ & $\begin{array}{c}\text { Fardani Annisa Damastuti } \\
\text { (Politeknik Elektronika Negeri } \\
\text { Surabaya, Indonesia); Artiarini } \\
\text { Nurindiyani (Lecturer, Politeknik } \\
\text { Elektronika Negeri Surabaya, } \\
\text { Indonesia) }\end{array}$ \\
\hline
\end{tabular}




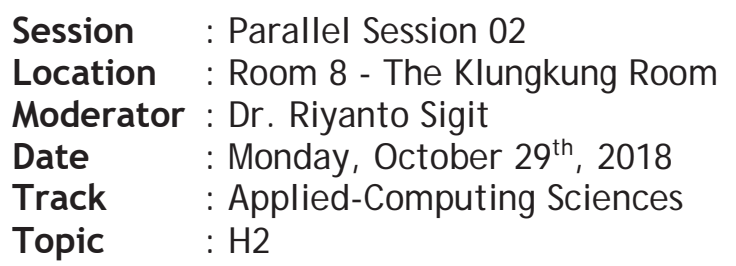

\begin{tabular}{|c|c|c|c|}
\hline Time & ID Paper & Title & Author(s) \\
\hline $16.00-16.15$ & 1570483666 & $\begin{array}{l}\text { Implementation of Microservice } \\
\text { Architectures on SEMAR } \\
\text { Extension For Air Quality } \\
\text { Monitoring }\end{array}$ & $\begin{array}{c}\text { Yohanes Panduman and Mochamad } \\
\text { Rifki Ulil Albaab (Politeknik } \\
\text { Elektronika Negeri Surabaya, } \\
\text { Indonesia); Adnan Rachmat Anom } \\
\text { Besari (Politeknik Elektronika Negeri } \\
\text { Surabaya (PENS), Electronic } \\
\text { Engineering Polytechnic Institute of } \\
\text { Surabaya (EEPIS), Indonesia); } \\
\text { Sritrusta Sukaridhoto (Politeknik } \\
\text { Elektronika Negeri Surabaya, } \\
\text { Indonesia); Anang Tjahjono (Pens, } \\
\text { Indonesia) }\end{array}$ \\
\hline $16.15-16.30$ & 1570483733 & $\begin{array}{l}\text { Segmentation of Liver Using } \\
\text { Abdominal CT Scan to Detection } \\
\text { Liver Desease Area }\end{array}$ & $\begin{array}{l}\text { Faizatul Himmah and Riyanto Sigit } \\
\text { (Politeknik Elektronika Negeri } \\
\text { Surabaya, Indonesia); Tri Harsono } \\
\text { (Electronics Engineering Polytechnic } \\
\text { Institute of Surabaya, Indonesia) } \\
\end{array}$ \\
\hline $16.30-16.45$ & 1570483750 & $\begin{array}{l}\text { Design and Implementation of } \\
\text { Middleware System for loT } \\
\text { Devices based on Raspberry Pi }\end{array}$ & $\begin{array}{c}\text { Muh Rifqi Rizqullah (Politeknik } \\
\text { Elektronika Negeri Surabaya, } \\
\text { Indonesia); Adnan Rachmat Anom } \\
\text { Besari (Politeknik Elektronika Negeri } \\
\text { Surabaya (PENS), Electronic } \\
\text { Engineering Polytechnic Institute of } \\
\text { Surabaya (EEPIS), Indonesia); Iwan } \\
\text { Kurnianto Wibowo (Electronic } \\
\text { Engineering Polytechnic Institute of } \\
\text { Surabaya, Indonesia); Ricky Setiawan } \\
\text { (Politeknik Elektronika Negeri } \\
\text { Surabaya, Indonesia); Dias Agata } \\
\text { (Poiliteknik Elektronika Negeri } \\
\text { Surabaya, Indonesia) }\end{array}$ \\
\hline $16.45-17.00$ & 1570483831 & $\begin{array}{l}\text { Strip Test Analysis Using Image } \\
\text { Processing for Diagnosing } \\
\text { Diabetes and Kidney Stone } \\
\text { Based on Smartphone }\end{array}$ & $\begin{array}{c}\text { Goestom Budianto (Politeknik } \\
\text { Elektronika Negeri Surabaya, } \\
\text { Indonesia); Tri Harsono (Electronics } \\
\text { Engineering Polytechnic Institute of } \\
\text { Surabaya, Indonesia); Heny Yuniarti } \\
\text { (Politeknik Elektronika Negeri } \\
\text { Surabaya, Indonesia) }\end{array}$ \\
\hline $17.00-17.15$ & 1570483924 & $\begin{array}{l}\text { Fetal Head and Femur Detection } \\
\text { from USG image to Estimate } \\
\text { Gestational Age }\end{array}$ & $\begin{array}{c}\text { Khusnul Danny Rahayu and Riyanto } \\
\text { Sigit (Politeknik Elektronika Negeri } \\
\text { Surabaya, Indonesia); Dias Agata } \\
\text { (Poiliteknik Elektronika Negeri } \\
\text { Surabaya, Indonesia) }\end{array}$ \\
\hline
\end{tabular}




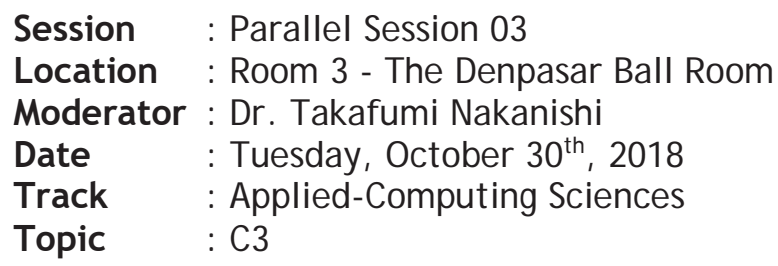

\begin{tabular}{|c|c|c|c|}
\hline Time & ID Paper & Title & Author(s) \\
\hline $10.30-10.45$ & 1570483941 & $\begin{array}{l}\text { Development of an e-Coin } \\
\text { System for managing user's } \\
\text { learning progress on different } \\
\text { e-learning applications }\end{array}$ & $\begin{array}{c}\text { Kohei Kamimura, Kazuki Naganuma } \\
\text { and Kosuke Takano (Kanagawa } \\
\text { Institute of Technology, Japan) }\end{array}$ \\
\hline $10.45-11.00$ & 1570484636 & $\begin{array}{l}\text { Text Steganography on } \\
\text { Sundanese Script using } \\
\text { Improved Line Shift Coding }\end{array}$ & $\begin{array}{c}\text { Henning Titi Ciptaningtyas (Institut } \\
\text { Teknologi Sepuluh Nopember (ITS) } \\
\text { Surabaya, Indonesia); Radityo } \\
\text { Anggoro (Institut Teknologi } \\
\text { Sepuluh Nopember, Kumamoto } \\
\text { University, Indonesia); Muhsin } \\
\text { Fadhillah (Institut Teknologi } \\
\text { Sepuluh Nopember (ITS) Surabaya, } \\
\text { Indonesia) }\end{array}$ \\
\hline $11.00-11.15$ & 1570484670 & $\begin{array}{l}\text { Mobile Learning Media for } \\
\text { Computer Science Course }\end{array}$ & $\begin{array}{c}\text { Edy Budiman, Novianti Puspitasari, } \\
\text { Masna Wati, Haeruddin Haeruddin, } \\
\text { J oan Angelina Widians and Andi } \\
\text { Tej awati (Universitas Mulawarman, } \\
\text { Indonesia) }\end{array}$ \\
\hline $11.15-11.30$ & 1570485895 & $\begin{array}{l}\text { Developing Web-Based English } \\
\text { Reading-Aloud Practice App } \\
\text { with Dictation Method Using } \\
\text { Speech Recognition } \\
\text { Technology }\end{array}$ & $\begin{array}{c}\text { Aliv Faizal Muhammad (Electronic } \\
\text { Engineering Polytechnic Institute } \\
\text { of Surabaya, Indonesia); Akhmad } \\
\text { Alimudin (Politeknik Elektronika } \\
\text { Negeri Surabaya, Indonesia) }\end{array}$ \\
\hline $11.30-11.45$ & 1570486209 & $\begin{array}{l}\text { Media-driven Real-time } \\
\text { Content Management } \\
\text { Framework and its Application } \\
\text { to In-Class Thinking Support } \\
\text { System }\end{array}$ & $\begin{array}{c}\text { Takafumi Nakanishi (International } \\
\text { University of J apan, Center for } \\
\text { Global } \\
\text { Communications(GLOCOM)/ Musashi } \\
\text { no University, J apan); Kyohei } \\
\text { Matsumoto (GLOCOM, International } \\
\text { University of J apan, J apan); } \\
\text { Toshitada Sakawa (Sakawa Co., } \\
\text { Ltd., J apan); Kengo Onodera } \\
\text { (TerraLin Create Co., Ltd., J apan); } \\
\text { Shinichiro Orimo and Hiroyuki } \\
\text { Kobayashi (Hirayama Elementary } \\
\text { School, Hino City, J apan) }\end{array}$ \\
\hline
\end{tabular}




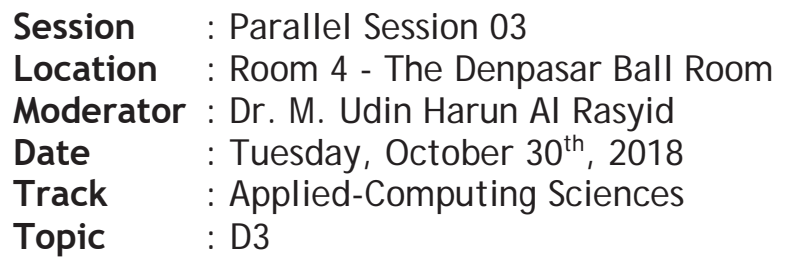

\begin{tabular}{|c|c|c|c|}
\hline Time & ID Paper & Title & Author(s) \\
\hline $10.30-10.45$ & 1570486437 & $\begin{array}{l}\text { Visualization of Gathering } \\
\text { Sources of News by J ournalist }\end{array}$ & $\begin{array}{c}\text { Hestiasari Rante, Muhammad } \\
\text { Agus Zainuddin, Fardani Annisa } \\
\text { Damastuti and Mudli'ul } \\
\text { Wahdaniyah (Politeknik } \\
\text { Elektronika Negeri Surabaya, } \\
\text { Indonesia) }\end{array}$ \\
\hline $10.45-11.00$ & 1570486532 & $\begin{array}{l}\text { Auto Cropping For Application of } \\
\text { Pancreas Abnormality Detection } \\
\text { In Order To Recognize Diabetes } \\
\text { Mellitus Through Iris Based on } \\
\text { Mobile Devices }\end{array}$ & $\begin{array}{c}\text { Entin Martiana Kusumaningtyas } \\
\text { (Politeknik Elektronika Negeri } \\
\text { Surabaya(PENS)-Indonesia, } \\
\text { Indonesia); Ali Ridho Barakbah } \\
\text { (Politeknik Elektronika Negeri } \\
\text { Surabaya, Indonesia) }\end{array}$ \\
\hline $11.00-11.15$ & 1570486835 & $\begin{array}{l}\text { Brain Tumor Segmentation to } \\
\text { Calculate Percentage Tumor } \\
\text { Using MRI }\end{array}$ & $\begin{array}{c}\text { Annisa Wulandari, Riyanto Sigit } \\
\text { and Mochamad Mobed Bachtiar } \\
\text { (Politeknik Elektronika Negeri } \\
\text { Surabaya, Indonesia) }\end{array}$ \\
\hline $11.15-11.30$ & 1570486989 & Learning Batik through Gaming & $\begin{array}{c}\text { Hestiasari Rante (Politeknik } \\
\text { Elektronika Negeri Surabaya, } \\
\text { Indonesia); Mohamad Safrodin } \\
\text { (PENS, Indonesia) }\end{array}$ \\
\hline $11.30-11.45$ & 1570487055 & $\begin{array}{l}\text { Anomalous Data Detection in } \\
\text { WBAN Measurements }\end{array}$ & $\begin{array}{l}\text { M. Udin Harun Al Rasyid and } \\
\text { Fajar Setiawan (Politeknik } \\
\text { Elektronika Negeri Surabaya } \\
\text { (PENS), Indonesia); Isbat Uzzin } \\
\text { Nadhori (Politeknik Elektronika } \\
\text { Negeri Surabaya - Indonesia, } \\
\text { Indonesia); Amang Sudarsono } \\
\text { (Politeknik Elektronika Negeri } \\
\text { Surabaya (PENS), Indonesia); } \\
\text { Ni'am Tamami (Politeknik } \\
\text { Elektronika Negeri Surabaya, } \\
\text { Indonesia) }\end{array}$ \\
\hline
\end{tabular}




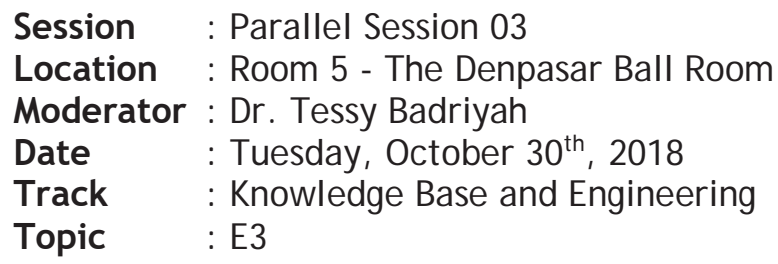

\begin{tabular}{|c|c|c|c|}
\hline Time & ID Paper & Title & Author(s) \\
\hline $10.30-10.45$ & 1570488512 & $\begin{array}{l}\text { Virtual Hand: VR Hand } \\
\text { Controller Using IMU and Flex } \\
\text { Sensor }\end{array}$ & $\begin{array}{c}\text { Hilman Mochamad, Dwi Kurnia } \\
\text { Basuki and Sritrusta Sukaridhoto } \\
\text { (Politeknik Elektronika Negeri } \\
\text { Surabaya, Indonesia) }\end{array}$ \\
\hline $10.45-11.00$ & 1570488578 & $\begin{array}{l}\text { Implementation of Entreprise } \\
\text { Resource Planning } \\
\text { Development In Cosmetic } \\
\text { Company Cosme Centre } \\
\text { Surabaya }\end{array}$ & $\begin{array}{l}\text { Kholid Fathoni and Festy Fildia } \\
\text { Siswanto (Politeknik Elektronika } \\
\text { Negeri Surabaya, Indonesia); J auari } \\
\text { Hasim (Electronic Engineering } \\
\text { Polytechnic Institute of Surabaya, } \\
\text { Indonesia) }\end{array}$ \\
\hline $11.00-11.15$ & 1570489120 & $\begin{array}{l}\text { IUGR (Intra Uterine Growth } \\
\text { Restriction) Diagnosis on the } \\
\text { Pregnancy using Naive Bayes } \\
\text { method }\end{array}$ & $\begin{array}{c}\text { Tessy Badriyah (Electronic } \\
\text { Engineering Polytechnic Institute } \\
\text { of Surabaya, Indonesia); Nadia } \\
\text { Savitri (Politeknik Elektronika } \\
\text { Negeri Surabaya, Indonesia); Umi } \\
\text { Saadah (Electronic Engineering } \\
\text { Polytechnic Institute of Surabaya, } \\
\text { Indonesia) }\end{array}$ \\
\hline $11.15-11.30$ & 1570472822 & $\begin{array}{l}\text { An Incremental Episodic } \\
\text { Memory Framework for Robot } \\
\text { Sensorimotor Map Building }\end{array}$ & $\begin{array}{c}\text { Wei Hong Chin and Azhar Saputra } \\
\text { (Tokyo Metropolitan University, } \\
\text { Japan); Yuichiro Toda (Okayama } \\
\text { University, J apan); Naoyuki Kubota } \\
\text { (Tokyo Metropolitan University, } \\
\text { Japan) }\end{array}$ \\
\hline $11.30-11.45$ & 1570475293 & $\begin{array}{l}\text { Visualization of Time Series } \\
\text { Change on GDP Per Electricity } \\
\text { by Provinces in Indonesia }\end{array}$ & $\begin{array}{c}\text { Yukari Shirota (Gakushuin } \\
\text { University, Japan); Alfan Presekal } \\
\text { (Universitas Indonesia, Indonesia); } \\
\text { Riri Fitri Sari (University of } \\
\text { Indonesia, Indonesia) }\end{array}$ \\
\hline
\end{tabular}




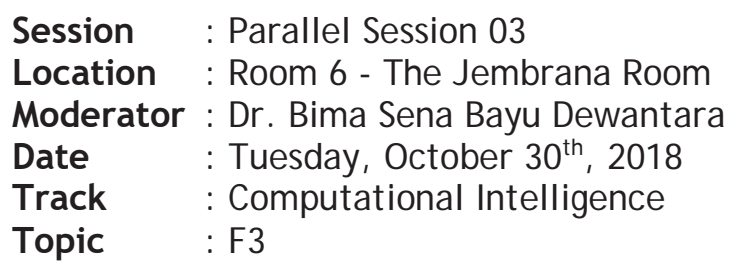

\begin{tabular}{|c|c|c|c|}
\hline Time & ID Paper & Title & Author(s) \\
\hline $10.30-10.45$ & 1570485825 & $\begin{array}{l}\text { Detection of Oil Condition on } \\
\text { Motorcycle Based on Sound } \\
\text { Signal Analysis }\end{array}$ & $\begin{array}{c}\text { Febrina Syafitri, Endah Suryawati } \\
\text { Ningrum and Zaqiatud Darojah } \\
\text { (Politeknik Elektronika Negeri } \\
\text { Surabaya, Indonesia) }\end{array}$ \\
\hline $10.45-11.00$ & 1570486495 & $\begin{array}{l}\text { Faster R-CNN Implementation } \\
\text { Method for Multi-Fruit } \\
\text { Detection Using Tensorflow } \\
\text { Platform }\end{array}$ & $\begin{array}{c}\text { Hasan Basri (Politeknik Elektronika } \\
\text { Negeri Surabaya, Indonesia); Iwan } \\
\text { Syarif (Politeknik Elektronika } \\
\text { Negeri Surabaya (PENS), } \\
\text { Indonesia); Sritrusta Sukaridhoto } \\
\text { (Politeknik Elektronika Negeri } \\
\text { Surabaya, Indonesia) }\end{array}$ \\
\hline $11.00-11.15$ & 1570489024 & $\begin{array}{l}\text { Early Warning and loT-based } \\
\text { Reporting System for Mobile } \\
\text { Trash Bin Robot Application }\end{array}$ & $\begin{array}{c}\text { Kisron Kisron and Bima Sena Bayu } \\
\text { Dewantara (Politeknik Elektronika } \\
\text { Negeri Surabaya, Indonesia); } \\
\text { Fernando Ardilla (Electronic } \\
\text { Engineering Polytechnic Institute } \\
\text { of Surabaya, Indonesia) }\end{array}$ \\
\hline $11.15-11.30$ & 1570477465 & $\begin{array}{l}\text { Tracks Record's Behaviour of } \\
\text { Virtual Tawaf Simulation using } \\
\text { A* Algorithm and RVO Sensor }^{*}\end{array}$ & $\begin{array}{c}\text { Moh. Zikky (Politeknik Elektronika } \\
\text { Negeri Surabaya); M J ainal Arifin } \\
\text { and Kholid Fathoni (Politeknik } \\
\text { Elektronika Negeri Surabaya, } \\
\text { Indonesia) }\end{array}$ \\
\hline $11.30-11.45$ & 1570477773 & $\begin{array}{l}\text { Developing Automatic Action } \\
\text { Camera Holder using 3D } \\
\text { Anaglyph for Creating 3D } \\
\text { Video }\end{array}$ & $\begin{array}{c}\text { Ragil Tawakal (Politeknik } \\
\text { Elektronika Negeri Surabaya, } \\
\text { Indonesia); Achmad Basuki } \\
\text { (Politeknik Elektronika Negeri } \\
\text { Surabaya, Indonesia); Akemad } \\
\text { Ragel and Nur Wulandari } \\
\text { (Politeknik Elektronika Negeri } \\
\text { Surabaya, Indonesia) }\end{array}$ \\
\hline $11: 45-12: 00$ & 1570481487 & $\begin{array}{l}\text { An Implementation of Data } \\
\text { Exchange in Environmental } \\
\text { Monitoring Using } \\
\text { Authenticated Attribute-Based } \\
\text { Encryption with Revocation }\end{array}$ & $\begin{array}{l}\text { Munsyi Munsyi (Universitas } \\
\text { Muhammadiyah Banjarmasin, } \\
\text { Indonesia); Amang Sudarsono and } \\
\text { M. Udin Harun Al Rasyid (Politeknik } \\
\text { Elektronika Negeri Surabaya } \\
\text { (PENS), Indonesia) }\end{array}$ \\
\hline
\end{tabular}




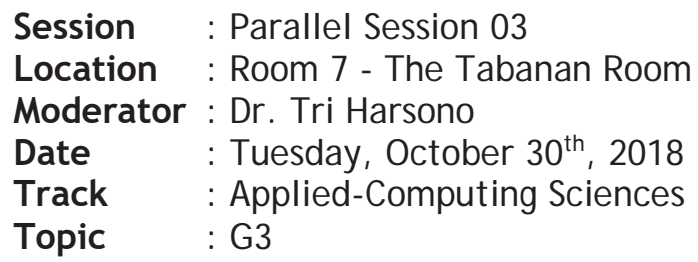

\begin{tabular}{|c|c|c|c|}
\hline Time & ID Paper & Title & Author(s) \\
\hline $10.30-10.45$ & 1570487088 & $\begin{array}{l}\text { Cloud Satellite Image } \\
\text { Segmentation using Meng Hee } \\
\text { Heng K-Means and DBSCAN } \\
\text { Clustering }\end{array}$ & $\begin{array}{c}\text { Nailus Sa'ada, S (Politeknik } \\
\text { Elektronika Negeri Surabaya, } \\
\text { Indonesia); Tri Harsono } \\
\text { (Electronics Engineering } \\
\text { Polytechnic Institute of Surabaya, } \\
\text { Indonesia); Achmad Basuki } \\
\text { (Politeknik Elektronika Negeri } \\
\text { Surabaya, Indonesia) }\end{array}$ \\
\hline $10.45-11.00$ & 1570487138 & $\begin{array}{l}\text { Fuzzy Logic and Exponential } \\
\text { Smoothing for Mapping } \\
\text { Implementation of Dengue } \\
\text { Haemorrhagic Fever in } \\
\text { Surabaya }\end{array}$ & $\begin{array}{c}\text { Muhammad Mufid (Electronic } \\
\text { Engineering Polytechnic Institute } \\
\text { of Surabaya (EEPIS), Indonesia); } \\
\text { Nilla Saginta Putri (Politeknik } \\
\text { Elektronika Negeri Surabaya, } \\
\text { Indonesia); Arna Fariza (Politeknik } \\
\text { Elektronika Negeri Surabaya, } \\
\text { Indonesia); Muarifin M (Politeknik } \\
\text { Elektronika Negeri Surabaya, } \\
\text { Indonesia) }\end{array}$ \\
\hline $11.00-11.15$ & 1570487144 & $\begin{array}{l}\text { Visual-based trash detection } \\
\text { and classification system for } \\
\text { smart trash bin robot }\end{array}$ & $\begin{array}{c}\text { Irfan Salimi and Bima Sena Bayu } \\
\text { Dewantara (Politeknik Elektronika } \\
\text { Negeri Surabaya, Indonesia); Iwan } \\
\text { Kurnianto Wibowo (Electronic } \\
\text { Engineering Polytechnic Institute } \\
\text { of Surabaya, Indonesia) }\end{array}$ \\
\hline $11.15-11.30$ & 1570488408 & $\begin{array}{l}\text { Online Video Conference } \\
\text { System Using WebRTC } \\
\text { Technology for Distance } \\
\text { Learning Support }\end{array}$ & $\begin{array}{c}\text { Akhmad Alimudin (Politeknik } \\
\text { Elektronika Negeri Surabaya, } \\
\text { Indonesia); Aliv Faizal Muhammad } \\
\text { (Electronic Engineering Polytechnic } \\
\text { Institute of Surabaya, Indonesia) }\end{array}$ \\
\hline $11.30-11.45$ & 1570488452 & $\begin{array}{l}\text { Distribution System for } \\
\text { Perishable Farming Product }\end{array}$ & $\begin{array}{c}\text { Isbat Uzzin Nadhori (Politeknik } \\
\text { Elektronika Negeri Surabaya - } \\
\text { Indonesia, Indonesia); Ahmad } \\
\text { Syauqi Ahsan (Politeknik } \\
\text { Elektronika Negeri Surabaya, PENS, } \\
\text { Indonesia) }\end{array}$ \\
\hline $11.45-12.00$ & 1570488583 & $\begin{array}{l}\text { Gas Billing System based on } \\
\text { Automatic Meter Reading on } \\
\text { Diaphragm Gas Meter with } \\
\text { Email Notification }\end{array}$ & $\begin{array}{c}\text { Fuad Irhandi Wiratama, Moch } \\
\text { Syaifuddin, Iwan Kurnianto Wibowo } \\
\text { and Fernando Ardilla (Electronic } \\
\text { Engineering Polytechnic Institute } \\
\text { of Surabaya, Indonesia); Andi } \\
\text { Purnomo (PT. Citra Nusantara } \\
\text { Energi, Indonesia) }\end{array}$ \\
\hline
\end{tabular}




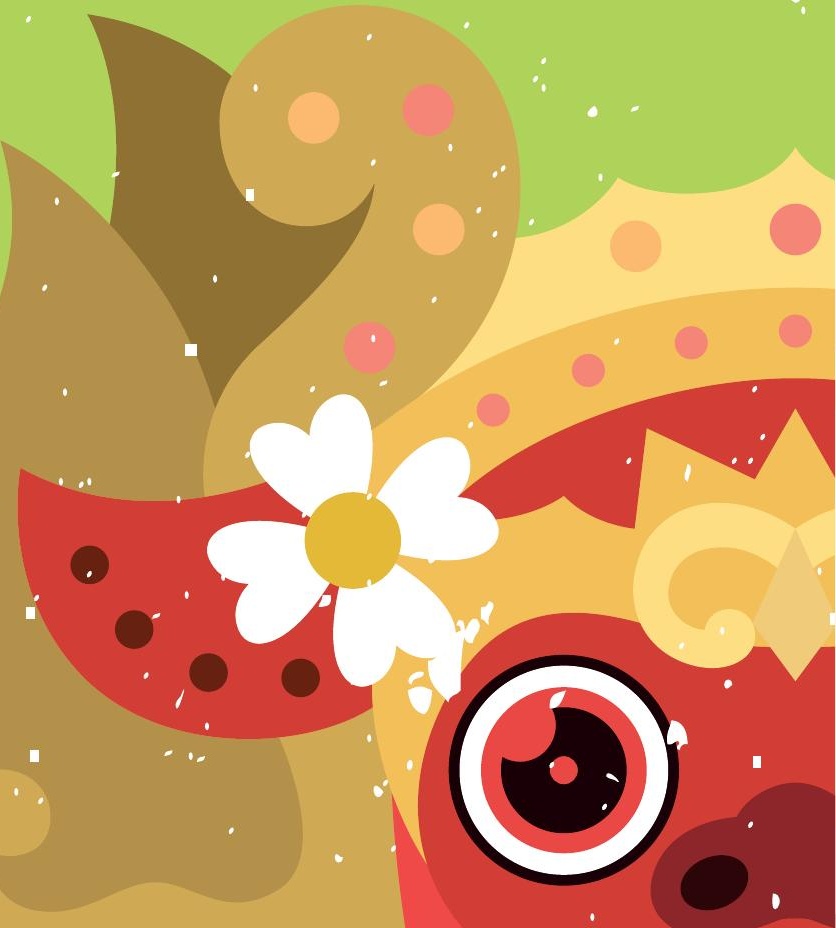

D

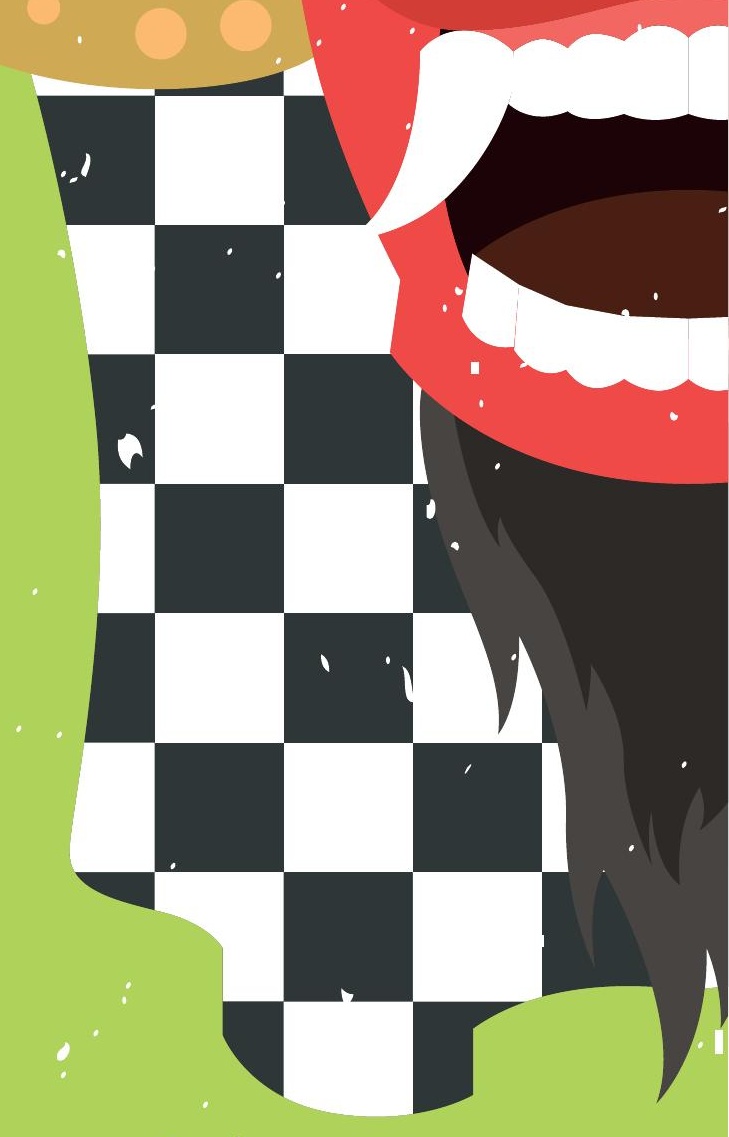

:

Kampus PENS Sukolilo Jl. Raya ITS, Keputih, Sukolilo, Keputih

Kota SBY, Jawa Timur 60111

Telp : +62 315947280

http://ies.pens.ac.id/2018/

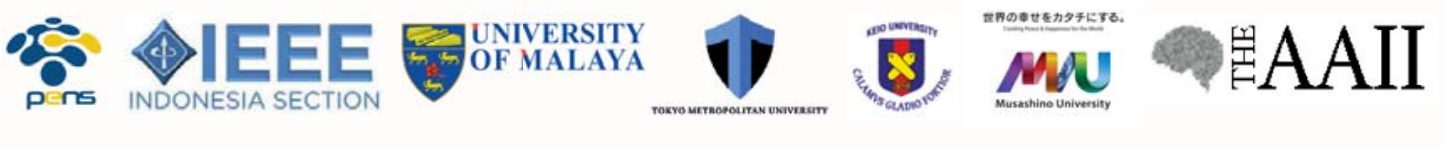




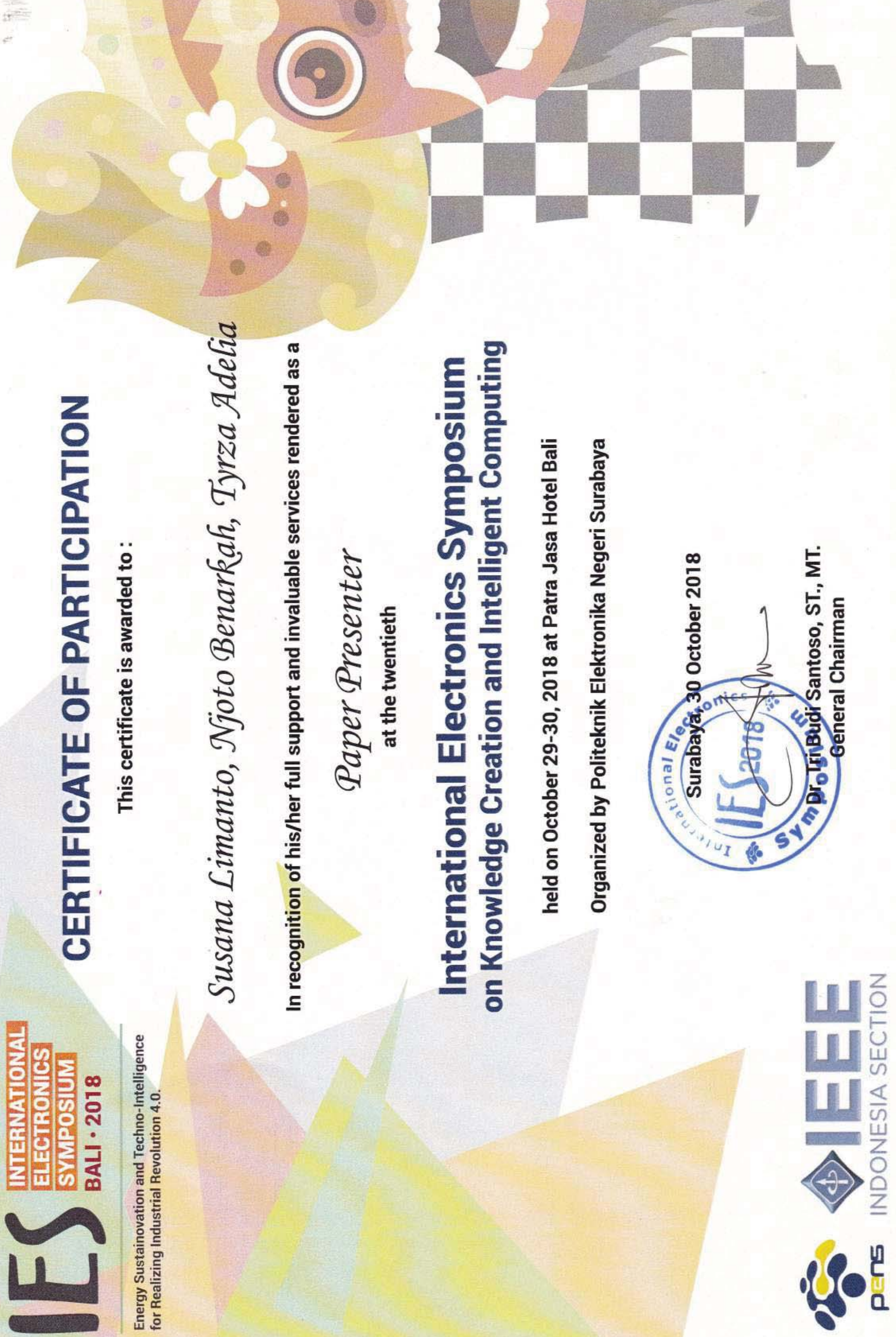


IEEE.org | IEEE Xplore Digital Library | IEEE-SA | IEEE Spectrum | More Sites

\section{Institutional Sign In}

Browse

Search within results
My Settings

Q
Get Help

Per Page: IE Per Page 25 | Expor|

Displaying 1 of 1 result for "First Name" susana × "Last Name" limanto $x$ Conferences (1)

\section{Show}

- All Results

Open Access

Year

Single Year Range

2018

2018

Author

Affiliation

\begin{tabular}{|c|c|}
\multicolumn{1}{c|}{ From } & To \\
2018 & 2018 \\
\hline
\end{tabular}

\section{Thesis Examination Timetabling using Genetic Algorithm}

Susana Limanto ; Njoto Benarkah ; Tyrza Adelia

2018 International Electronics Symposium on Knowledge Creation Intelligent Computing (IES-KCIC)

Year: 2018

Pages: 6 - 10

\section{IEEE Conferences}

Abstract

(721 Kb)

Thesis Examination Timetabling using Genetic Algorithm Susana Limanto | Njoto Benarkah | Tyrza Adelia

2018 International Electronics Symposium on Knowledge Creation anc Intelligent Computing (IES-KCIC)

Year: 2018

IEEE websites place cookies on your device to give you the Pblalshęser experience. By using our websites, you agree to the placement of these cookies. To learn more, read our Accept \& Close 
IEEE websites place cookies on your device to give you the best user experience. By using our websites, you agree to the placement of these cookies. To learn more, read our Privacy Policy. 

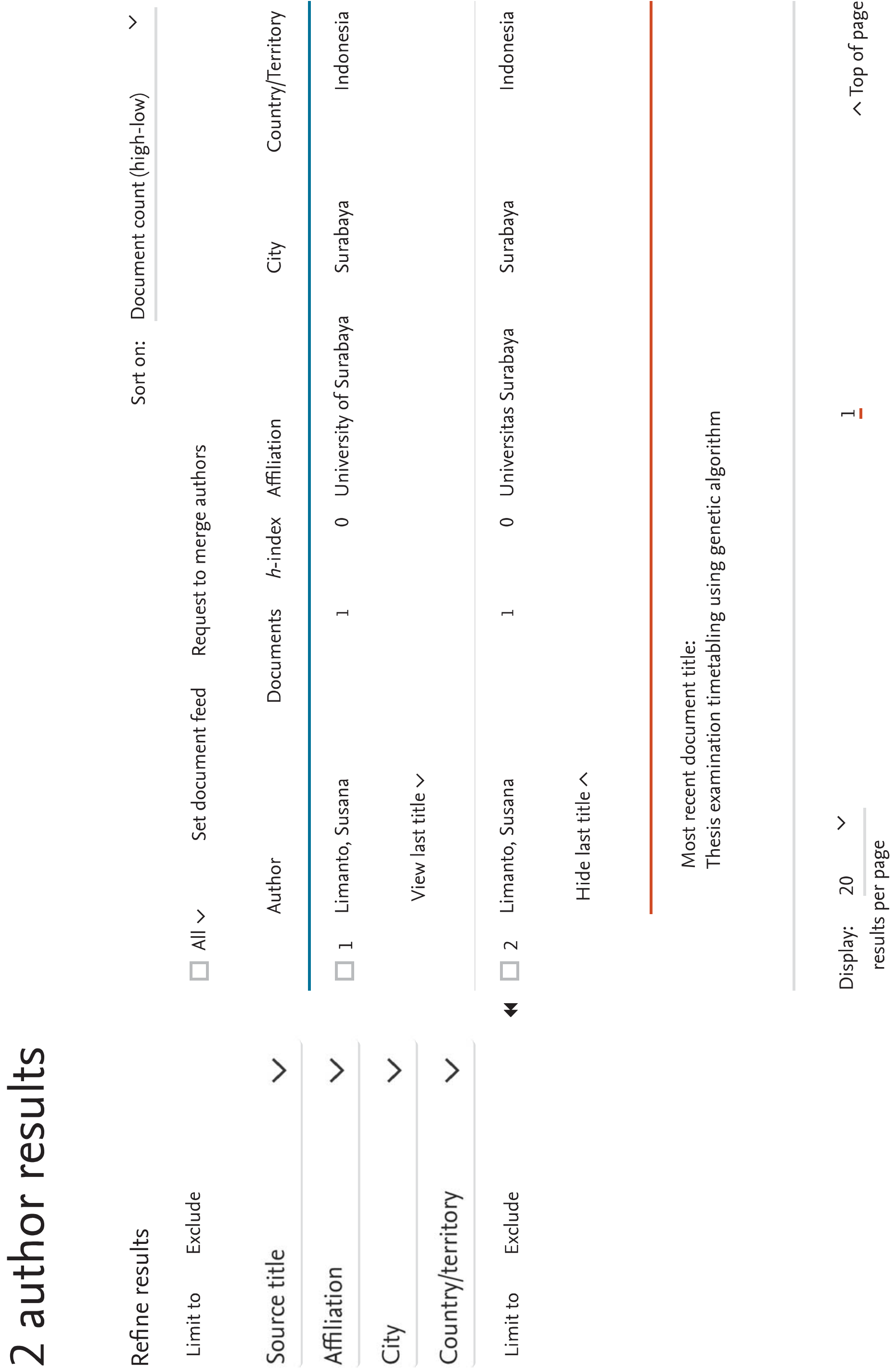



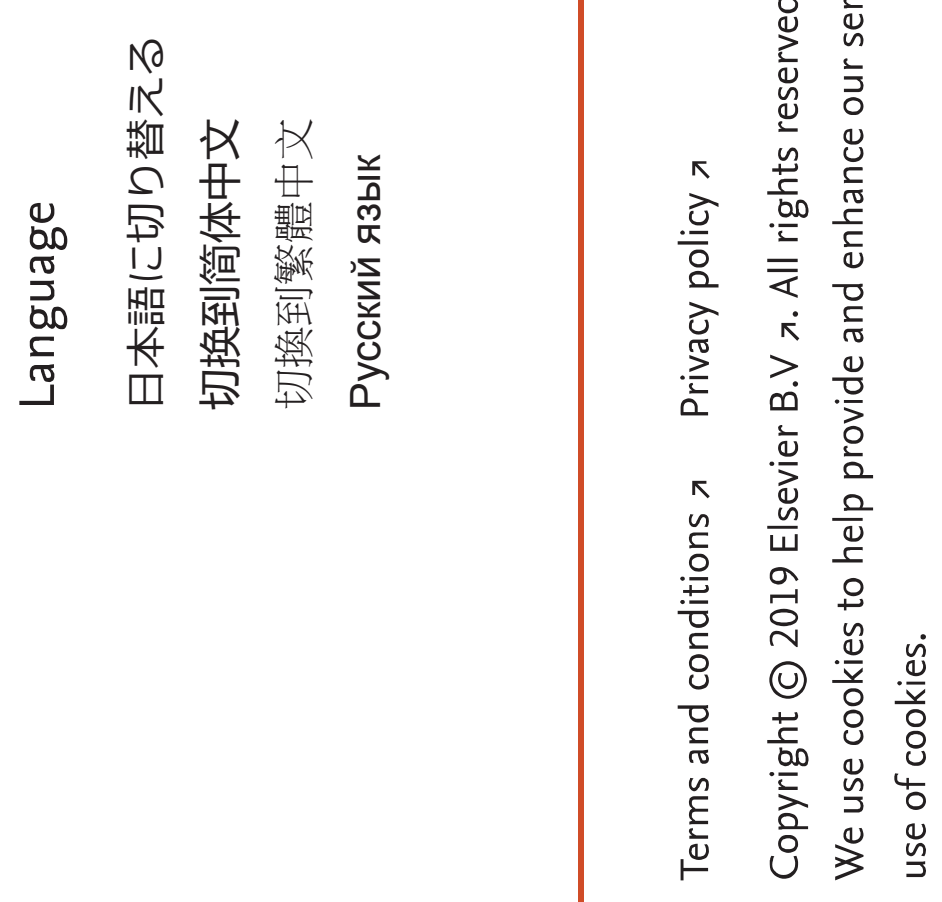

$n$
0
0
0
$ن$

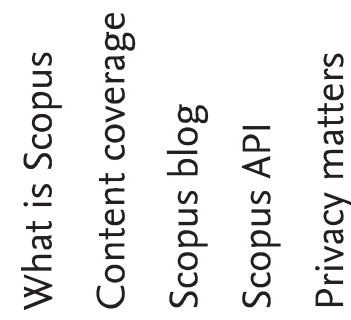

$>\quad$

๑

㐫

혼

㻤

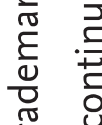

\pm ते

莡

$\stackrel{\sim}{\underline{0}} \frac{\overline{0}}{\pi}$

(2)

늘 믇

응

ง

¿ृ

ญั

$\kappa \quad$

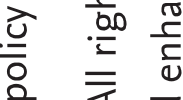

む)

2 $\frac{\dot{0}}{\overline{0}}$

$\begin{array}{lll}\kappa & \bar{d} & \frac{a}{0} \\ & \frac{0}{\omega} & \frac{0}{d}\end{array}$

बे

○) (1) $\frac{.}{v}$

ᄃ

है 


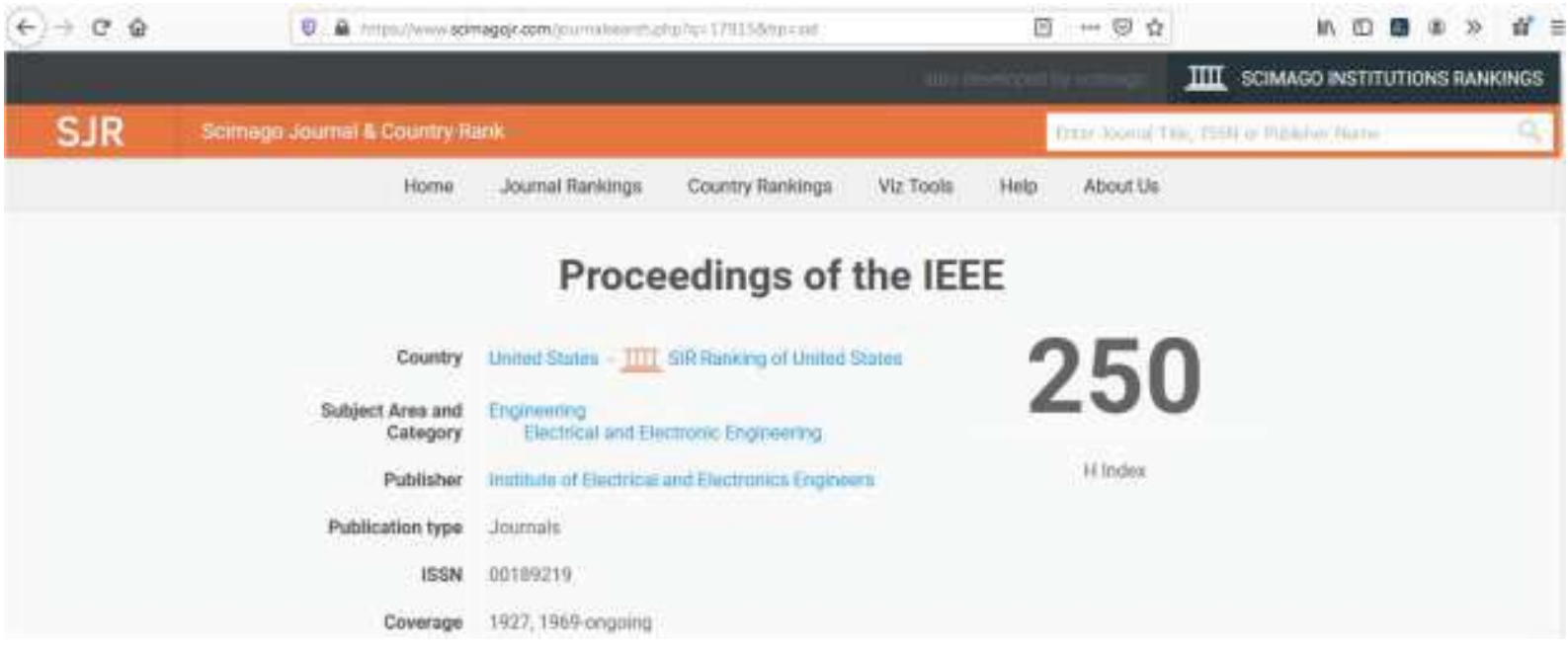
Scope Proceedings of Be iEEE a the feading joumas to provbie in inpeh teview, aurvey, and tutonal

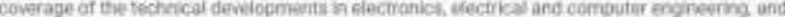

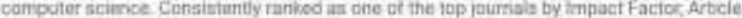

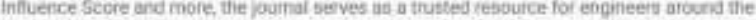

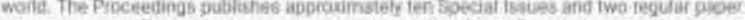 issies per yoar, Speclal issues ara led by distingushed Guest Eultor tearns and contan articles

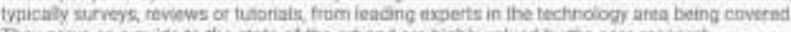

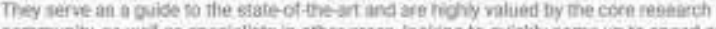 cormmunity, as wed as ippecialstu in ocher arest. locking to Quckly come up to speed on the

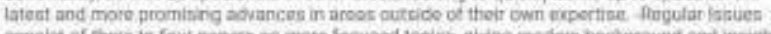

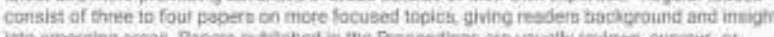 into emerging sreas. Papers putishet in the Proceedicgs at o uscatly reviens, surmys, or

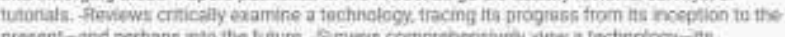

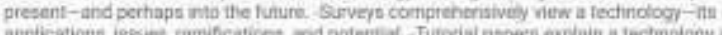

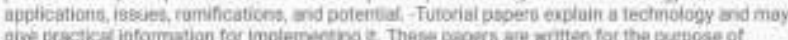

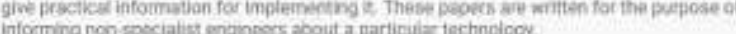
(i) Homepage
Hew Io pubitah miths peanep
Cantact
S. Join the cotwernanam aheut fivip purng

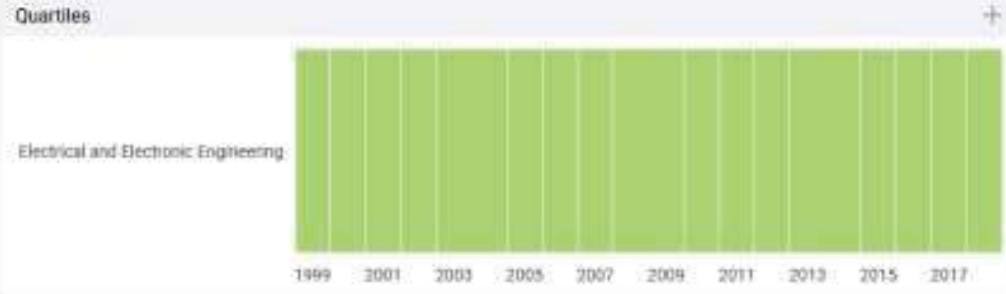



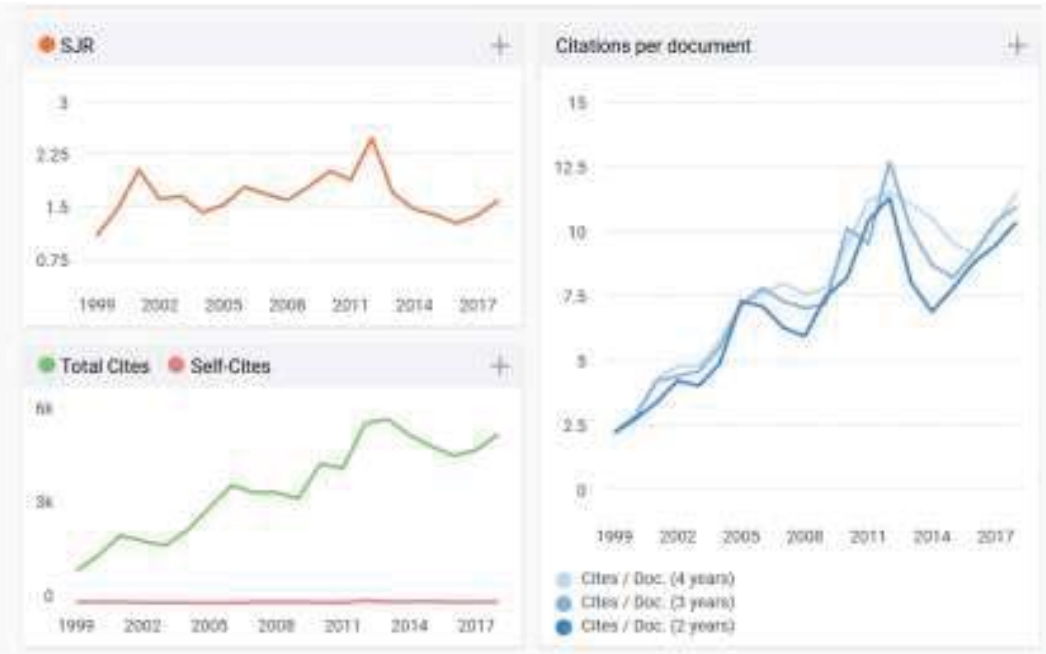

$1999 \quad 2002 \quad 2005 \quad 2000$ 2011 2014 2017

a- Cites r Doc. (4 ytano

ec clear doc. (a) mans
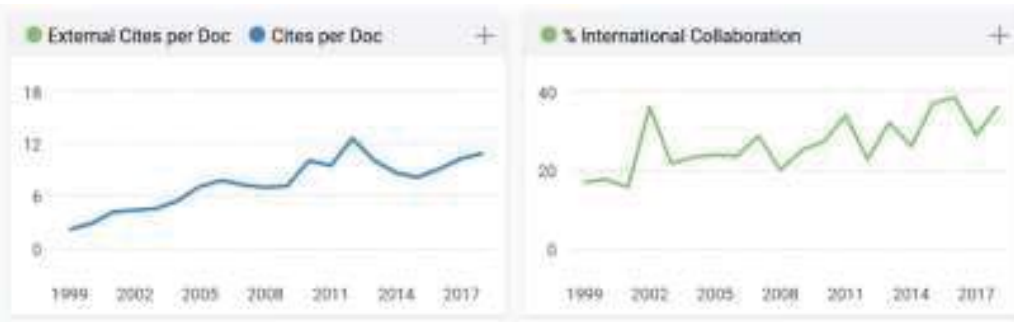

- Cable documents En-chable documents t B.00

- Ched documents e uncited documents + poo

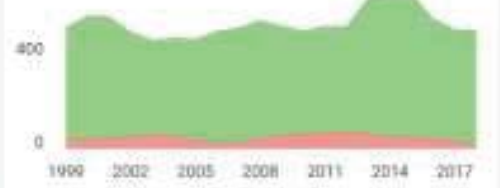

asc

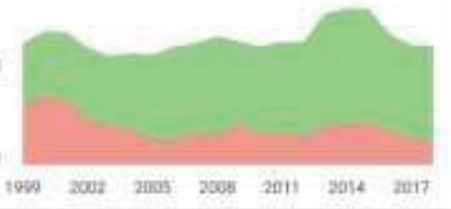

